NBSIR 81-2444

\title{
Smoke Movement Through A Suspended Ceiling System
}

U.S. DEPARTMENT OF COMMERCE

National Bureau of Standards

National Engineering Laboratory

Center for Fire Research

Washington, DC 20234

Issued:

February 1982

Final Report

Funded in part by:

Veterans Administration

Office of Construction Research ashington, DC 20420

epartment of Health and Human Services ashington, DC 20201 



\section{SMOKE MOVEMENT THROUGH A SUSPENDED CEILING SYSTEM}

John H. Klote

U.S. DEPARTMENT OF COMMERCE

National Bureau of Standards

National Engineering Laboratory

Center for Fire Research

Washington, DC 20234

Issued:

February 1982

Final Report

Funded in part by:

Veterans Administration

Office of Construction Research

Washington, DC 20420

Department of Health and Human Services

Washington, DC 20201

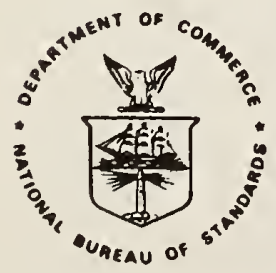

U.S. DEPARTMENT OF COMMERCE, Malcolm Baldrige, Secretary NATIONAL BUREAU OF STANDARDS, Ernest Ambler, Director 

Page

LIST OF FIGURES . . . . . . . . . . . . . . . . . . v v

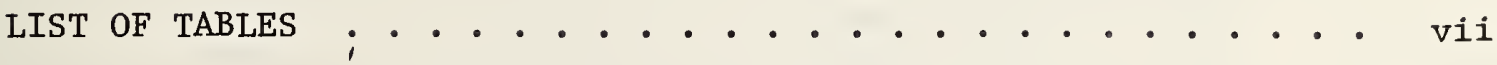

Abstract . . . . . . . . . . . . . . . . . . . 1

1. INTRODUCTION . . . . . . . . . . . . . . . . 2

2. TEST FACILITY . . . . . . . . . . . . . . . . 3

3. EXPERTMENTAL DETAILS . . . . . . . . . . . . . 5

3.1 Instrumentation . . . . . . . . . . . . . . 5

3.1.1 Temperature . . . . . . . . . . . . . . 5

3.1.2 Smoke Obscuration ............. 5

3.1.3 Carbon Monoxide ............... 5

3.1 .4 Velocity .................. 6

3.2 Test Program .................... . . . 6

3.3 Test Procedures .................. . . . . . 6

3.3.1 Smoke Candle Test . . . . . . . . . . 6

3.3.2 Smoldering Tests .............. 7

3.3.3 Low Energy Tests .............. 7

3.3.4 High Energy Tests . . . . . . . . . . 8

3.4 Mattresses and Bedding . . . . . . . . . . . 8

3.4.1 Low Energy Tests . . . . . . . . . . . 8

3.4.2 High Energy Tests.............. . 9

4. HAZARD ANALYSIS ................... . . . 9

4.1 Smoke Obscuration ................ . . 10

4.2 Carbon Monoxide ................... . . 10

5. TEST RESULTS AND DISCUSSION . . . . . . . . . . . 11

5.1 Smoke Candle Test . . . . . . . . . . . . . . 11

5.2 Smoldering Tests . . . . . . . . . . . . . 12

5.2.1 Tests 1 and 2................ 12

5.2.2 Test 3 ................ . . . 13

5.3 Low Energy Tests . . . . . . . . . . . . . . 14

5.3.1 Tests 4 and 5............... 14

5.3.2 Test 6 ................ 15

5.3 .3 Test 7 . . . . . . . . . . . . 16

5.3 .4 Test 8 . . . . . . . . . . . . . 16

5.3 .5 Test 9 . . . . . . . . . . . . 17

5.3.6 Test 10 ................ . . . 18 
5.4 High Energy Tests . . . . . . . . . . . . 19 5.4.1 Tests 11 and 12 .............. . . 19 5.4.2 Smoke Leakage into Room 2 . . . . . . . . 20 5.4.3 Smoke Movement through the Ceiling . . . . . 21

5.5 Comparison of Test Types . . . . . . . . . . . 22 5.5.1 Smoke Movement.............. 22 5.5.2 Hazardous Conditions ............ . 22 5.5.3 Smoke Detection ............. . 23

5.6 Interstitial Space Exhaust . . . . . . . . . . 24

5.7 Patient Room Exhaust . . . . . . . . . . . . 26

5.8 Smoke Movement Paths . . . . . . . . . . . 27

6. SUMMARY AND CONCLUSIONS . . . . . . . . . . . . . 28

7. ACKNOWLEDGEMENTS . . . . . . . . . . . . . . . 30

8. REFERENCES . . . . . . . . . . . . . . . . . 31 
Figure 1. Floor plan of test facility . . . . . . . . . 33

Figure 2. Section of test facility . . . . . . . . . . 34

Figure 3. Ceiling plan of test facility . . . . . . . . 35

Figure 4. Ventilation system for test facility . . . . . . 36

Figure 5. Instrumentation plan for test facility . . . . . . 37

Figure 6. Instrumentation plan for interstitial space . . . . 38

Figure 7. Instrumentation in burn room doorway . . . . . . 39

Figure 8. Instrumentation in burn room . . . . . . . . 40

Figure 9. Instrumentation in room 1 . . . . . . . . . 41

Figure 10. Floor plan for test facility showing status of doors and windows during the tests . . . . . . . 42

Figure 11. Smoke obscuration for the smoke candle test . . . . 43

Figure 12. Smoke obscuration in the burn room and the interstitial space for tests 1 and 2 . . . . . . . . 44

Figure 13. Smoke obscuration in the burn room and the interstitial space for tests 2 and 3 . . . . . 45

Figure 14. Upper gas temperatures for tests 4 through 7 . . . 46

Figure 15. Upper gas temperatures for tests 8 through 10 . . 47

Figure 16. Smoke obscuration for tests 4 and 5 . . . . . . 48

Figure 17. Smoke obscuration for test 5 . . . . . . . . 49

Figure 18. Carbon monoxide concentrations for test 5 . . . . 50

Figure 19. Smoke obscuration for test 6 . . . . . . . . 51

Figure 20. Smoke obscuration for test 7 . . . . . . . 52

Figure 21. Carbon monoxide concentrations for tests 6 and 7 . 53

Figure 22. Smoke obscuration for test 8 . . . . . . . . 54 


\section{LIST OF FIGURES (cont'd)}

Page

Figure 23. Smoke obscuration for test 9........... 55

Figure 24. Smoke obscuration for test 10 . . . . . . . . 56

Figure 25. Temperatures for test 11 . . . . . . . . . 57

Figure 26. Temperatures for test 12 . . . . . . . . 58

Figure 27. Smoke obscuration for tests 11 and 12 . . . . . . 59

Figure 28. Carbon monoxide concentrations for tests 11 and 12 . 60

Figure 29. Pressure difference across burn room ceiling for

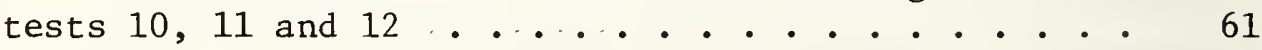

Figure 30. Smoke obscuration for the smoke candle test and test 1.......................... 62 
Table 1. Fan Schedule . . . . . . . . . . . . 63

Table 2. List of Instrumentation . . . . . . . . . . . . 64

Table 3. Test Schedule . . . . . . . . . . . . . 66

Table 4. Ignition Source . . . . . . . . . . . . 67

Table 5. Technical Data for Mattress and Bedding for

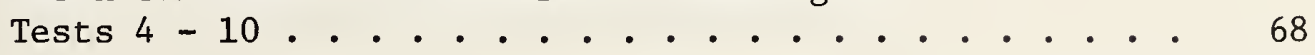

Table 6. Technical Data for Mattress and Bedding for

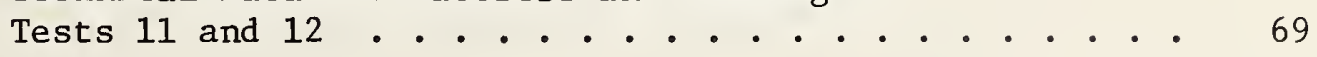

Table 7. Times to Hazard Level Due to Co Concentrations . . . . 70

Table 8. Smoke Detector Activation Times . . . . . . . . 71 

SMOKE MOVEMENT THROUGH A SUSPENDED CEILING SYSTEM

John H. Klote

Abstract

A series of full-scale tests were conducted to evaluate smoke movement through a suspended ceiling and into an interstitial space of a hospital type facility. A test facility specifically constructed for this project is described. The test series consisted of one smoke candle test and 12 fire tests including both smoldering and flaming fires. Smoke movement through the suspended ceiling system was evaluated in terms of the total smoke movement through the test facility. The effects of ventilation and smoke exhaust on smoke concentration in the test facility were investigated. It was concluded that the use of the interstitial space exhaust as described in this paper will effectively prevent hazard conditions due to smoke downflow through suspended ceilings. It was also concluded that smoldering fires of the type examined in this test series are not a significant problem in hospitals.

Key words: Ceiling systems; hazard analysis; hospitals; interstitial space; mattresses; smoke control; smoke exhaust; smoke movement; ventilation systems. 


\section{INTRODUCTION}

Smoke $^{1}$ is commonly recognized as a major killer in building fires. One of the reasons for this is that smoke flows through numerous leakage paths to locations remote from the fire, resulting in a hazard to human life. These leakage paths can be open doors, cracks around closed doors, stairwells, elevator shafts, construction cracks in walls and floors, and even cracks or openings in a suspended acoustical ceiling.

Extensive use of suspended acoustical ceilings has resulted in questions within the Veterans Administration (VA) and among the fire protection community regarding the potential of danger resulting from smoke leakage through the ceiling. This is especially true for cases where there are large areas above the suspended ceiling, such that smoke could travel through these paths to locations remote from the fire. Such smoke movement could involve smoke movement up through the ceiling, horizontal flow in the space above the ceiling, and then downward flow into an occupied space.

This paper reports the results of a test series conducted to evaluate smoke movement through a suspended ceiling system. Particular emphasis in this study was directed toward examining this problem under a construction arrangement typical of a hospital. A test facility was constructed which consisted of four patient rooms and a section of corridor. Above these spaces there was an open space referred to as the interstitial space. The interstitial space was separated from the lower spaces by a suspended ceiling system. In hospitals the interstitial space is typically used for mechanical and electrical equipment, ductwork, piping, and conduit.

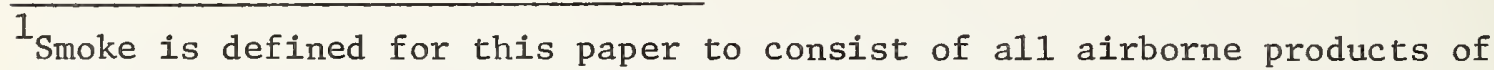
combustion including both particles and gases.
} 
In this test series the extent of smoke penetration through the ceiling was evaluated from (1) smoke candles, (2) smoldering fires, low energy flaming fires, and (4) high energy flaming fires. Smoke concentrations were determined by measuring smoke obscuration and $\mathrm{CO}$ concentration. Smoke concentrations were recorded in a number of locations throughout the test facility in order to evaluate smoke movement through the ceiling system in light of smoke movement throughout the rest of the test facility. The effects of the ventilation, occupancy space exhaust, and interstitial space smoke exhaust on smoke concentration in the test facility were also investigated. In addition, a hazard analysis, limited to smoke obscuration and co concentration, is included.

\section{TEST FACILITY}

The test facility was built inside another structure to minimize the effect of the wind. This facility has four patient rooms and a section of corridor as shown in figure 1. The burn room has one door to the corridor and another smaller door to the space outside the test facility. This smaller door was included to provide a convenient exit. This door was closed throughout all the tests except for the first 5 to 10 seconds of each test when the person who ignited the test fire was exiting. Reference in this report to the "burn room door" will mean the door between the burn room and the corridor.

The doors throughout the test facility had polymer seals on both sides and the top. These seals were a commercial product which was specifically made for use on metal door frames. The sealing mechanism was a thin polymer leaf against which the door closed. Small leakage paths existed at the corners where these seals met. The doors were undercut $23 \mathrm{~mm}(7 / 8 \mathrm{in})$. No attempt was made to seal these cracks at the bottom of the doors from the four rooms into the corridor. However, bottom sweeps were installed on the two doors to the outside of the test facility. 
Figure 2 shows a section through the test facility. The walls of the facility consist of $16 \mathrm{~mm}$ (5/8 in) type $\mathrm{X}$ gypsum board on steel studs. All of the gypsum board joints were taped and spackled. The perimeter walls of the test facility have gypsum board on the interior side only. The interior walls are $2.44 \mathrm{~m}(8 \mathrm{ft})$ high and have gypsum board on both sides. The suspended ceilings are separately hung in each room.

The ceiling was constructed of $0.61 \times 1.22 \mathrm{~m}$ (24 $\times 48 \mathrm{in}$ ) acoustical tiles supported by a steel grid system. The ceiling plan is shown in figure 3. The construction of the ceiling was (see figure 2) in accordance with the ceiling portion of UL listing A202 [1] ${ }^{2}$, floor ceiling assembly, with the exception that ceiling hold down clips were left off one ceiling tile in each room and one tile in the corridor. These uncliped tiles were used as access panels. In addition, an open cell polymer seal was installed between the ceiling wall molding and the wall, as is common practice in Veterans Administration hospitals. The ceiling tiles weighed $49.6 \mathrm{~N} / \mathrm{m}^{2}\left(1.001 \mathrm{~b} / \mathrm{ft}^{2}\right)$.

The ventilation system for the test facility is shown in figure 4. This system consists of supply and exhaust for the four patient rooms as well as ventilation for the interstitial space. Table 1 is a schedule of the ventilation fans. The system was designed and balanced to provide six air changes per hour in the patient rooms. Four radial fans were installed for ventilation of the interstitial space. These fans are capable of being repositioned in the ductwork so that they can be used for either supply or exhaust of the interstitial space. Each radial fan has a damper for adjusting air flow. During this test series the only radial fan used was fan 5 in the exhaust mode. A11 of the outside air dampers were motorized.

${ }^{2}$ Numbers in brackets refer to references listed at the end of this paper. 


\section{EXPERIMENTAL DETAILS}

\subsection{Instrumentation}

The instruments used in this test series are shown in figures 5 thru 9 and are 1isted in table 2. Response times of smoke detectors and a tell-tale sprinkler were recorded automatically by activation of a relay which stopped a clock. All tests were recorded with $35 \mathrm{~mm}$ still camera or on video tape with separate coverage in the burn room and in the interstitial space. Generally, all instrumentation channels were recorded at 20 second intervals for the smoldering tests and at 13 second intervals for the flaming tests. The data acquisition system was located in an instrumentation trailer adjacent to the main building.

\subsubsection{Temperature}

Temperatures in the test facility were measured at locations shown in figures 5 thru 9, and outside air temperature was measured. These temperatures were measured by bare beaded chrome1-alumel thermocouples made from $0.51 \mathrm{~mm}$ (24 gauge) diameter wire.

\subsubsection{Smoke Obscuration}

The obscuration of smoke was measured at 12 locations as shown in figures 5 thru 9. The smoke meters measured optical density over a $1.0 \mathrm{~m}$ ( $3.28 \mathrm{ft}$ ) horizontal path using spotlights as 1ight sources and using photodiodes (PIN 3DP) as receivers.

\subsubsection{Carbon Monoxide}

Carbon monoxide (CO) was continuously measured at five locations as shown in figures 5 thru 9. In rooms 1, 2, and 3 the Co sample probes were located at approximately head height for a patient laying in bed. In the burn room the co sample probe was located approximately 
$0.91 \mathrm{~m}$ ( $3 \mathrm{ft}$ ) above the bed. This location was chosen so that it would collect smoke from the fire plume. Another co probe was located at approximately the mid-height of the interstitial space. Co concentrations were measured with nondispersive, infrared analyzers.

\subsubsection{Velocity}

Air and gas velocity were measured in the burn room doorway and the window in room 2 . In both cases the velocity was measured $0.1 \mathrm{~m}$ ( $4 \mathrm{in}$ ) below the top and $0.1 \mathrm{~m}$ ( $4 \mathrm{in}$ ) above the bottom of the opening. The room 1 window was open only for tests 1 thru 3 and accordingly the velocity at this window was recorded for these tests only. Velocities were measured with bidirectional probes [2] connected to variable reluctance differential pressure transducers.

\subsection{Test Program}

The smoke leakage performance of the ceiling system was tested with smoke generated by four types of sources: (1) smoke candle, (2) smoldering fire, (3) low energy flaming fire, and (4) high energy flaming fire. Throughout the tests the doors to rooms 1 and 3 were open and the door to room 2 was closed. The status of doors and windows for all the tests is shown in figure 10. The test schedule for all of the tests except the smoke candle test is listed in table 3 .

\subsection{Test Procedures}

\subsubsection{Smoke Candle Test}

A commercially available three minute duration smoke candle was set in the center of the flat steel surface of the hospital bed and ignited. Visual observations were made and the test was recorded on video tape. This test was performed so that smoke movement from smoke candles could be compared with smoke movement from real fires. 


\subsubsection{Smoldering Tests}

A smoldering fire of high reproducibility was developed for these tests. The pallet for the smoldering fires was constructed in the following steps:

a. Fiberglass insulation $0.58 \mathrm{~mm}$ (23 in) wide and $89 \mathrm{~mm}(3.5$ in) thick was placed over a plywood board $1.83 \mathrm{~m} \mathrm{x} 0.58 \mathrm{~m} \mathrm{x}$ $13 \mathrm{~mm}$ (72 in $\times 23$ in $\times 1 / 2$ in) thick.

b. Three layers of untreated cotton batting $0.69 \mathrm{~m}$ (27 in) wide and $25 \mathrm{~mm}$ ( 1 in) thick were placed on top of the fiberglass.

c. A bedspread of 50 percent polyester and 50 percent cotton was placed on top.

d. The assembly was then turned over, compressed with approximately $70 \mathrm{~N}$ (16 1b) force and the spread was pulled tight and stapled securely on both sides.

The pallet was placed with the plywood side down on the hospital bed in the burn room. Three slits were made in the pallet, approximately $76 \mathrm{~mm}$ ( $3 \mathrm{in}$ ) long and $40 \mathrm{~mm}$ (1.6 in) deep into the cotton batting. One of these slits was located in the center of the pallet and the other two were located $0.61 \mathrm{~m}$ (24 in) from each end and equidistant from the sides. The pallet was ignited by placing a lighted half cigarette in each slit and then pushing the slit shut. The cotton batting had been stored in a room at 30 percent $\mathrm{RH}$ and $21^{\circ} \mathrm{C}\left(70^{\circ} \mathrm{F}\right)$.

\subsubsection{Low Energy Tests}

These tests are referred to as low energy tests because the mattress was filled with fire retardant treated cotton padding. A detailed description of the mattress and bedding for these tests is provided in section 3.4.1. The fire was started in a steel wastebasket 
containing 20 sheets of newspaper of which ten crumpled and ten were rolled and placed vertically. The wastebasket was placed in contact with the blanket and top sheet. Each test began when the contents of the wastebasket were ignited with a cigarette lighter. All bedding and wastepaper were kept in a storage room where the humidity was in the range of $30-50$ percent $\mathrm{RH}$ and the temperature was in the range of $16-23^{\circ} \mathrm{C}\left(60-74^{\circ} \mathrm{F}\right)$.

\subsubsection{High Energy Tests}

These tests were referred to as high energy tests because the mattress was filled with polyurethane foam. A detailed description of the mattress and bedding for these tests is provided in section 3.4.2. The mattress was one which has been used as part of the NBS mattress flammability test program [3, 4, 5]. A polyethylene wastebasket filled with $443 \mathrm{~g}(.97 \mathrm{lb})$ of combustibles was placed next to the bed as was done in the NBS mattress tests. Table 4 lists the contents of the wastebasket. The wastebasket was placed in contact with the bedspread. Each test began when the contents of the wastebasket were ignited with a cigarette lighter. All bedding and wastebasket items were kept in a 50 percent $\mathrm{RH}$ conditioning room at a temperature of $21^{\circ} \mathrm{C}\left(70^{\circ} \mathrm{F}\right)$ for at least 24 hours prior to each test in order to be consistent with the prior NBS mattress tests [3].

\subsection{Mattresses and Bedding}

\subsubsection{Low Energy Tests}

The mattresses and bedding for the low energy flaming tests were supplied by the Veterans Administration. The mattress was an innerspring mattress constructed of fire retardant treated cotton felt padding with a retardant treated vinyl impregnated nylon tick covering (outermost layer). The bedding consisted of a bianket, two sheets, a pillow and a pillow case. The pillow had cotton ticking and was filled with duck feathers. A detailed description of the mattress and bedding is provided in table 5. For test 4, the first low energy flaming test, 
a fire retardant blanket of a matrix fiber of 50 percent vinyl and 50 percent vinyon was used. In this test only the newspaper in the wastebasket and a small amount of the cotton sheet burned. Because the fire intensity was so $10 \mathrm{w}$, it was decided to use a cotton blanket furnished by the Veterans Administration for subsequent low energy tests.

\subsubsection{High Energy Tests}

The mattress and bedding for the high energy tests were the same as the mattress and its bedding materials used in the NBS mattress test program [3]. The mattress chosen was a polyurethane innerspring one which was coded M-02 in the mattress tests. The bedding was obtained from a commerical hospital supplier and was intended for use in health care facilities. The bedding consisted of a cotton drawsheet, two sheets, and a bedspread, a pillow case and pillow filled with shreaded polyurethane foam. A detailed description of the mattress and bedding is 1 isted in table 6 .

\section{HAZARD ANALYSIS}

The primary objective of this project was to study smoke movement through the interstitial space resulting from a fire originating below the space in an occupied room. In addition, a limited discussion regarding the resultant hazard to human life from such fires is also presented. For this paper the hazard analysis was limited to smoke obscuration and $\mathrm{CO}$ concentration. It should not be inferred that $\mathrm{CO}$ is the only toxic gas that is significant in fire situations. This was the only gas measured due to the limited scope of the project. In this discussion of hazard analysis, temperature was not considered because the primary concern of this study is with the hazards associated with smoke at locations where there is negligible temperature rise due to the fire. 


\subsection{Smoke Obscuration}

The limiting level of smoke obscuration for human safety was selected for two separate hazards in this fire test scenario. The first concerned rescue of a patient from a patient room, and the second involved the use of the corridor as an exit way. Obscuration was measured at a number of locations (section 3.1.2) in order to study smoke movement. For hazard analysis only the smoke meters located 1.5 $\mathrm{m}$ ( $5 \mathrm{ft}$ ) above the floor in the patient rooms and in the corridor were considered. Critical levels of obscuration selected for each location were based on investigations by Jin [6, 7]. Jin recommended limits on obscuration based on not reducing the walking speed below that of a blindfolded subject in a smoke free environment. This obscuration was approximately $0.25 \mathrm{oD} / \mathrm{m}$. Accordingly, in this paper, the value of 0.25 $\mathrm{OD} / \mathrm{m}$ is used as the critical level of smoke obscuration for both the patient rooms and the corridor.

\subsection{Carbon Monoxide}

CO forms carboxyhemoglobin ( $\mathrm{COHb}$ ) in the blood and thereby reduces the oxygen carrying capacity of the blood. Therefore, percent $\mathrm{COHb}$ is a meaningful measure of $\mathrm{CO}$ toxicity. The following approximate procedure, adopted for this test program to evaluate $\mathrm{COHb}$, has been employed by $0^{\prime} \mathrm{Neill}$ and Hayes $[4,5]$.

Steward derived an equation of $\mathrm{COHb}$ from experiments with human volunteers [8]. The volunteers were subjected to very high concentrations of $\mathrm{CO}$ and their $\mathrm{COHb}$ levels were then measured. $\mathrm{CO}$ uptake is directly proportional to the breathing rate which is approximately $6.5 \mathrm{l} / \mathrm{min}$ for an individual at rest. The breathing rate increases with activity and also from exposure to $\mathrm{CO}_{2}$. A 4 percent concentration of $\mathrm{CO}_{2}$ will more than double the breathing rate [9]. Since both of these factors must be considered in a fire situation, a breathing rate of $18 \mathrm{l} / \mathrm{min}$ was selected for purposes of analysis. The equation developed based on Steward's work for determining $\mathrm{COHb} \%$ is: 


$$
\Delta \mathrm{COHb} \%=5.98 \times 10^{-4}(\Delta \mathrm{t})[\mathrm{CO}]^{1.036}
$$

where $\Delta t$ is time in minutes and $C O$ is concentration in ppm. An initial value of 0.75 percent $\mathrm{COHb}$ was established, based on information provided by Alarie and Zu1lo [10] for use in the computation. A 25 percent calculated COHb was selected in this study as the critical level of $\mathrm{COHb}$ at which incipient incapacitation may occur [11].

In addition to the threshold for time-rated accumulation, another limit must be selected for $\mathrm{CO}$ exposure. Instantaneous doses of high levels of co must also be considered due to the physiological effects such as cardiac arrhythmia [12] which can occur independently of the effects of increased COHb. Claudy [13] reported on the effects of exposure to high concentrations of $\mathrm{Co}$. The results of his work indicate that incipient incapacitation may occur with only a few short breaths at an exposure level of 10,000 ppm Co. And, at a slightly higher concentration of $12,800 \mathrm{ppm}$ Claudy reported that unconsciousness could occur in 2 to 3 breaths, followed by death in 1-3 minutes. Based on this an instantaneous threshold of $10,000 \mathrm{ppm}$ ( 1.0 percent by Vol) Co was selected as a criterion, in addition to the time integrated exposure resulting in COHb level of 25 percent.

\section{TEST RESULTS AND DISCUSSION \\ 5.1 Smoke Candle Test}

The smoke candle test was conducted under the following conditions:

1. The burn room door was closed.

2. The window to room 1 was open.

3. The supply and exhaust systems for the four patient rooms were operating.

4. The interstitial space exhaust fans were off.

5. The status of the other doors and the windows was the same as for all of the other tests, as listed in table 3. 
As expected, visual observation revealed that the smoke filled the burn room quickly, but there was a much lower level of smoke in the other rooms, the corridor and the interstitial space. Figure 11 indicates that the optical density in the corridor and the interstitial space was considerably lower than the optical density in the burn room. In addition, it was observed that the major path of smoke movement through the suspended ceiling was at joints between the walls and the metal wall molding of the suspension system, in spite of the fact that these joints were filled with open cell foam. In section 5.5, this smoke candle test is compared with the other tests conducted in this series.

\subsection{Smoldering Tests}

In the first three tests, the burn room door was closed and smoldering fires were set as described in section 3.3.1. The test conditions for these tests are summarized in table 3. Throughout all three tests there was only slight visible smoke in the corridor and rooms 1,2 , and 3 . Visual observation after 60 minutes revealed that small quantities of smoke were flowing under the burn room door into the corridor. The co concentrations outside the burn room were negligible. In all three tests the temperature outside the burn room remained constant, and the temperature $0.1 \mathrm{~m}$ ( 4 in) below the burn room ceiling only increased by $8^{\circ} \mathrm{C}$.

\subsubsection{Tests 1 and 2}

Test 1 was conducted with the supply air and exhaust air on and all the ceiling tiles in place. In order to determine the effect of missing ceiling tiles, test 2 was conducted with two ceiling tiles missing from the burn room ceiling. Figure 12 shows smoke obscuration in the burn room and interstitial space for these two tests. The data from test 1 is for less than 60 minutes because of a failure in the data acquisition software. As expected the obscuration is greater in the interstitial space in test 2 with the ceiling tiles missing from the burn room. 


\subsubsection{Test 3}

In order to determine the effect of the ventilation system on smoke movement, test 3 was a repeat of test 2 except that the supply and exhaust fans to the four patient rooms were shut off. Figure 13 shows the smoke obscuration in the burn room and the interstitial space for tests 2 and 3 showing. There is a substantial increase in smoke concentration when the ventilation system is off.

The window in room 1 was open throughout these tests to determine the effect of an open window on smoke movement. In all three smoldering tests there was flow into room 1 at the bottom of the window and out of room 1 at the top. The air velocities at the window fluctuated in the range of 0 to $0.5 \mathrm{~m} / \mathrm{s}$ ( 0 to $0.15 \mathrm{ft} / \mathrm{s}$ ). This type of $\mathrm{flow}$ is indicative of natural air currents which exist in buildings, and would be unusual for a window open to the outside. In such cases the flow is usually dominated by either wind or stack effect or by both. Accordingly, the flow would be in one direction across the opening. Because the burn room door was closed, the open window in room 1 probably had no significant effect on the smoldering fire. However, for tests with the burn room door open, the open window would probably have an affect on the fire. This would impair reproducibility of the tests and yield no benefits. For this reason the window in room 1 was closed for all further tests.

During the smoldering tests the smoke obscuration and CO concentrations did not result in a significant threat to life. Co levels in the burn room were below 0.15 percent for all three tests, and $\mathrm{COHb}$ levels for a person in the burn room were well below the critical level. Smoke obscuration was below critical level throughout tests 1 and 2. And, in test 3 smoke obscuration remained below the critical level for the first 30 minutes of the test. 
A worry with a smoldering fire is that it will continue until hazardous conditions result, or until the fire develops into a flaming fire. While there was only the slightest visible smoke in the corridor and in rooms 1,2 and 3 , a very irritating smell was present in these spaces after the first few minutes of each test. It is apparent from figures 12 and 13 that smoke obscuration due to the smoldering fires is below the hazard level for at least a half hour. Hospitals have people who are awake 24 hours a day who can smell these fires and then easily extinguish them. Therefore, smoldering fires of the type examined in this test series do not appear to represent a serious problem in hospitals.

\subsection{Low Energy Tests}

In tests 4 through 10, fire retardant cotton mattress and bedding as described in section 3.4.1 were burned. The test conditions for these tests are summarized in table 3. The burn room door was open for a11 tests, with the exception of test 7 . The window in room 1 was closed for all tests for reasons discussed in section 5.2.2. The status of al1 windows and doors for these tests is provided in figure 10 . Figures 14 and 15 show the upper gas temperatures in the burn room for these tests.

\section{3 .1 Tests 4 and 5}

Test 4 was conducted with both the supply air and the exhaust air on. For this test a fire retardant blanket was used on the bed. This blanket was very successful in limiting the growth of the fire as can be seen from the upper gas temperature in figure 14. Test 5 was the same as test 4 except that a cotton blanket was used to increase the fire intensity. This was successful and cotton blankets were used for the rest of the low energy tests. Figure 16 shows smoke obscuration in the corridor and in the interstitial space for both test 4 and 5 . It is apparent that the smoke obscuration is much greater in test 5 when the cotton blanket was on the bed. 
During test 5 the burn room and rooms 1 and 3 were open to the corridor. It was visually observed that these spaces filled with smoke after about 2 or 3 minutes. This is also apparent from the smoke obscuration data shown in figure 17. As would be expected the corridor was obscured slightly before rooms 1 and 3 . The door to room 2 was closed throughout the test series, and smoke was observed flowing under the door and into room 2. It can be seen from figure 17 that the smoke obscuration in room 2 was considerably lower than that of the corridor or other rooms. Figure 17 shows that the obscuration of the interstitial space during test 5 was much lower than that of the corridor or that of rooms 1 and 3 . This indicates that the smoke flow through the open doorway was much greater than that through the ceiling system. During this test there was no indication of smoke movement from the interstitial space to room 2 .

Similar observations regarding smoke movement can be obtained by examining CO concentration. Figure 18 shows $C O$ concentrations for test 5. The co concentrations in the burn room, and rooms 1 and 3 were relatively high, while the concentrations in room 2 and the interstitial space are negligible. It can be observed from figure 18 that the burn room concentration of $\mathrm{CO}$ is about twice that measured in rooms 1 and 3 . This is because the burn room Co probe samples the gas from the fire plume.

\subsubsection{Test 6}

The test conditions for test 6 were the same as those for test 5 except that the supply air and the return air were shut off. This test was conducted to determine the extent to which smoke obscuration would increase without ventilation. Figure 19 shows smoke obscurations for test 6 . As in test 5 the optical density in the corridor and rooms 1 and 3 increased rapidly while the optical density in the interstitial space and room 2 was much lower. As in test 5 it is apparent that the smoke flow through the open doorway was much greater than the upward smoke flow through the ceiling system. There were no indications of smoke flowing from the interstitial space into room 2 . 
In comparing smoke obscuration from tests 5 and 6 (figures 17 and 19), it is apparent that the increase in smoke obscuration is dramatic when the ventilation is shut off. This is especially so for room 2 where the optical density was five times greater when the ventilation was off.

\section{3 .3 Test 7}

Test 7 was conducted to determine the effect of a closed burn room door on smoke concentration. This test was the same as test 6 except for the closed door. Figure 20 shows smoke obscurations for test 7 . By comparing figures 19 and 20 it is apparent that closing the burn room door significantly reduces the smoke obscuration in the corridor and in rooms 1, 2, and 3. However, these figures also show that closing the burn room door has essentially no effect on smoke obscuration in the interstitial space. This is probably because the major path of smoke movement into the interstitial space is through the burn room ceiling in either case. In addition, there were no indications of smoke flowing from the interstitial space into room 2.

Figure 21 shows CO concentration in the burn room and in room 1 for tests 6 and 7. This data shows that closing the burn room door results in increased $\mathrm{CO}$ in the burn room and decreased $\mathrm{CO}$ in room 1 . The burn room CO concentration is increased to the extent that in test 7 the critical level of $\mathrm{COHb}$ is reached in 22.6 minutes. However, in all the other low energy tests where the burn room door was open the critical level was not reached.

\section{3 .4 Test 8}

Test 8 was performed to determine the effect of exhausting two air changes per hour from the interstitial space. With the exception of exhausting the interstitial space, the conditions of this test were the same as those of test 6 . It was expected that exhausting the interstitial space would act to pull smoke through the ceiling and into the 
interstitial space. Accordingly, the level of smoke in the corridor and patient rooms would decrease. Figure 22 shows smoke obscuration for test 8. In comparing the results of tests 6 and 8 (figures 19 and 22), it is apparent that exhausting the interstitial space did indeed result in reduced smoke obscuration in the corridor and in rooms 1, 2, and 3 . Unfortunately, this reduction in obscuration did not result in greatly reduced hazard conditions. It can also be noticed by comparing figures 19 and 22, that exhausting the interstitial space had little effect on the smoke obscuration in the interstitial space. In this test, as in earlier tests, smoke was observed leaking into room 2 through the crack under the door. It should be noted that there were no indications of smoke flowing from the interstitial space into room 2.

\subsubsection{Test 9}

In order to determine the leakage paths into room 2 and to reconfirm the results of test 8 , test 9 was conducted. Test 9 was the same as test 8 except that the cracks around the door to room 2 were sealed with tape. Figure 23 shows smoke obscuration for test 9 . In comparing the smoke obscuration for tests 8 and 9 (figures 22 and 23), it is apparent that there was good repeatability between the two tests everywhere except in room 2. As expected, the two figures show that the smoke obscuration in room 2 was lower with the cracks around the door taped. It was observed during test 9 that smoke was flowing into room 2 through the exhaust gril1. The exhaust and supply systems were off, and apparently smoke traveled from the burn room to room 2 through the exhaust duct.

As in test 8 , the interstitial space exhaust had little effect on the smoke obscuration in the interstitial space, and there was no indication of smoke movement from the interstitial space into room 2. 


\subsubsection{Test 10}

Test 10 was conducted to determine the effect of operating the exhaust system for the patient rooms during a low energy fire. The door to room 2 was still sealed, and during the test no visible smoke was observed in room 2. This can be seen from the smoke obscuration data for test 10 which is provided in figure 24. The reasons for the absence of smoke in room 2 during this test are discussed in detail in section 5.7 .

Test 10 is the same as test 6 except that the exhaust air system is on in test 10. Comparison of the smoke obscuration for tests 5 and 10 (figures 19 and 24) shows that the obscuration throughout the facility was considerably lower when the exhaust air was on. This result was anticipated because test 10 is very similar to test 5 (figure 17) where both the exhaust and supply were operating. However, the smoke obscuration from test 10 was lower than that for test 5, indicaring that exhaust alone does more to eliminate smoke than exhaust and supply together.

An explanation which might be proposed for this is that the supply system provides combustion air which increases the combustion rate. This explanation does not consider that when the supply fan is off there is an inflow of outside air through whatever small cracks exist in the test facility. This inflow equals the exhaust rate and would also provide combustion air to the fire.

In addition, smoke feedback into the supply air system did not occur because the supply air was completely taken from the outside on the opposite side of the building from where the exhaust air was rejected (figure 4). Another possible effect is that the supply air reduced the ability of the exhaust system to remove smoke from the patient rooms. The supply diffusers were located approximately in the middle of each patient room (figure 3) and the return air grills were located $6 \mathrm{ft}$ 
above the floor in each patient room (figures 1 and 4 ). Because of the proximity of the diffusers and exhaust grill it is likely that the supply air diluted the smoke flowing into the exhaust system. This would reduce the smoke exhaust capability of the exhaust system.

\subsection{High Energy Tests \\ 5.4.1 Tests 11 and 12}

In tests 11 and 12, polyurethane mattress and bedding as described in section 3.3.4 were burned. The test conditions for these tests are listed in table 3. The burn room door was open for both of these tests. The status of all doors and windows in the test facility is provided in figure 10. Figures 25 and 26 show temperatures for tests 11 and 12 . These figures indicate that these tests were highly repeatable.

Test 11 was conducted with all the ventilation fans shut off. For tests 11 and 12, the door to room 2 was sealed to determine the extent of smoke movement through the duct work. Under these circumstances the smoke movement into room 2 would be similar to that into a room which had solid partitions separating it from the fire space. In test 11 as in test 9 smoke was observed flowing into the room 2 through the exhaust duct.

Test 12 was conducted with the air exhausted from the interstitial space at a rate of 2 air changes per hour. The exhaust grill and the supply register in room 2 were sealed off to determine other possible paths of smoke into room 2 .

During both tests 11 and 12 visual observation revealed that shortly after ignition there was considerable smoke flow out of the top of the burn room door, and that after about 2 minutes the corridor, and rooms 1 and 3 were obscured with smoke. In addition, during the first 4 minute of tests 11 and 12, smoke was observed flowing into the interstitial space through the cracks between the wall molding and the wall. And, at about 4 minutes the interstitial space filled very rapidly with smoke. 
Figure 27 shows smoke obscuration for tests 11 and 12 . This confirms the visual observations, described above. Similar trends can be found by observing the CO concentrations shown in figure 28 . After about 4 minutes the $C O$ concentration in room 1 increased rapidly, while the $C O$ concentrations in the interstitial space increased at a somewhat lower rate.

It is also apparent from figure 28 that the co concentrations in room 1 were lower in test 12 when the interstitial space was exhausted. This is similar to the reduced smoke concentrations caused by interstitial exhaust during the low energy fires of tests 8 and 9 . It can be observed from both figures 27 and 28 that exhausting the interstitial space has little effect on the smoke concentrations in the interstitial space.

\subsubsection{Smoke Leakage into Room 2}

The effect of sealing the return grill and the supply diffusers in room 2 should reduce the smoke concentrations in that room by preventing smoke movement through the duct systems. This behavior can be observed by examining smoke obscuration in figure 27 or by examining $\mathrm{Co}$ concentration in figure 28. Smoke obscuration and calculated COHb in room 2 were both well below the critical levels selected for this study. The concentration of $\mathrm{CO}$ in room 2 was below the instantaneous threshold. However, if the fire had been of longer duration it is possible that the smoke obscuration and $\mathrm{COHb}$ might have exceeded critical levels in room 2 .

During test 12 smoke may have infiltrated room 2 through the suspended ceiling, through cracks around the door frame, through cracks between the partitions, etc. Upon examination before and after test 12 , traces of smoke movement were evident on the ceiling tile around the diffusers in room 2. Visual examination of these smoke traces could not conclusively determine the direction of this smoke movement. It should be pointed out that in a real hospital the interstitial space would be 
many times larger, and therefore the smoke in the interstitial space would be more diluted. This indicates that any smoke flow down through a ceiling system would probably result in smoke concentrations even lower than those in room 2 during test 12 .

\subsubsection{Smoke Movement through the Ceiling}

The discussion of tests 11 and 12 in section 5.4 .1 included a description of the smoke concentrations in the interstitial space. During the first 4 minutes of these tests, smoke was observed flowing from the burn room into the interstitial space through the cracks between the ceiling wall molding and the wall. Apparently, the open cell foam (section 2) used to seal these cracks was ineffective in stopping smoke movement. At approximately 4 minutes into the test, it was observed that the smoke in the interstitial space increased very rapidly. This rapid increase in smoke concentration in the interstitial space can be observed from the co concentrations shown in figure 28 and from smoke obscuration in figure 27.

After test 11 the ceiling of the burn room was still intact. However, the metal suspension system was warped which resulted in a large number of cracks which would let smoke flow into the interstitial space. It can be observed from figure 25 that the gas temperature $0.1 \mathrm{~m}$ (4 in) below the burn room ceiling was very high; it peaked at $725^{\circ} \mathrm{C}$ $\left(1340^{\circ} \mathrm{F}\right)$ at about 6 minutes into the test. It seems apparent that the high temperature of the combustion gases near the ceiling warped the suspension system and that a greatly increased flow of smoke through the ceiling system resulted. This accounts for the rapid increase in smoke in the interstitial space at about 5 minutes into the test. After test 11 the burn room ceiling was rebuilt for test 12 .

Figure 29 shows the pressure difference across the burn room ceiling (see instrument number 56 on figure 8). For this figure a positive pressure indicates that the burn room is at a higher pressure than the interstitial space. It can be observed from figure 29 that in 
both tests 11 and 12 the pressure increased to about $9 \mathrm{~Pa}$ (0.036 inch $\mathrm{H}_{2} \mathrm{O}$ ) at about 5 minutes into the test. Then the pressure suddenly dropped to below $1 \mathrm{~Pa}\left(0.004\right.$ inch $\left.\mathrm{H}_{2} \mathrm{O}\right)$. This drop in pressure coincides with the rapid increase in smoke concentration in the interstitial space. When the suspension system warped, the increased leakage area resulted in both increased gas flow into the interstitial space and decreased pressure differential across the ceiling. It can also be observed from figure 29 that the differential pressures across the ceiling were larger for test 12 . This was due to the presence of interstitial exhaust during test 12 .

\subsection{Comparison of Test Types}

\subsubsection{Smoke Movement}

It is well known that the movement of smoke produced by smoke candles is significantly different than the movement of smoke produced by flaming fires. This is because the smoke from smoke candles lacks the buoyant forces which exist in smoke produced by flaming fires. However, one might think that smoke movement due to smoke candles and smoldering fires would be very similar because in both cases the buoyant forces of the smoke are negligible. A comparison of smoke obscuration for the smoke candle test and test 1 (figure 30) shows that this is not the case. The reason for this is that the rates of smoke production are very different. The smoke candle releases a large quantity of smoke in about three minutes, while the smoldering fire releases smoke slowly for about an hour. Therefore, the smoke movement due to a smoke candle is considerably different from that due to either a flaming test or a smoldering test.

\subsubsection{Hazardous Conditions}

During the three smoldering tests the Co concentration was considerably below the instantaneous threshold and the calculated $\mathrm{COHb}$ was well below the critical level. In the first two smoldering tests (figure 12) smoke obscuration was below the critical level. For test 3 
when the ventilation system was off the smoke obscuration (figure 13) was below the critical level throughout the facility except for the burn room. Even in the burn room the hazard level was not reached until 30 minutes into test 3 .

In the low and high energy tests smoke obscuration was more severe. With the exception of test 7 all of these tests were conducted with the burn room door open. Test 4 was unique in that a fire retarded blanket was on the bed. With the exception of tests 4 and 7 , smoke obscuration for both the low and high energy tests followed the same pattern, i.e. smoke from the burn room flowed into the corridor and then into rooms 1 and 3. Obscuration of these spaces reached the critical level at 1 to 3 minutes into each test.

However, the danger due to CO concentration was very different for the low and high energy tests. The $\mathrm{COHb}$ reached the critical level in the burn room for test 7 , a low energy test, at $22.6 \mathrm{~min}$. This measurement was not very meaningful for hazard analysis because it was measured $1.53 \mathrm{~m} \mathrm{(5} \mathrm{ft)} \mathrm{above} \mathrm{the} \mathrm{floor} \mathrm{over} \mathrm{the} \mathrm{bed} \mathrm{in} \mathrm{the} \mathrm{fire} \mathrm{plume.} \mathrm{The}$ critical level of $\mathrm{COHb}$ was not reached for any other low energy tests. However, critical levels of $\mathrm{COHb}$ and the instantaneous threshold of $\mathrm{CO}$ were reached for several locations in the test facility during the high energy tests. The times required to reach the critical level of COHb and the instantaneous threshold of $\mathrm{co}$ are listed in table 7.

\subsubsection{Smoke Detection}

Smoke detectors were included in this test series to examine their performance. The ionization detectors used for this test series were the same type as used by Bukowski [14] in a study of detector performance in health care occupancies. Bukowski reported activation times during flaming tests of 15 to $45 \mathrm{~s}$ for ionizing detectors in the burn room and 50 to $115 \mathrm{~s}$ for ionizing detectors in the corridor. 
Throughout this test series smoke detectors were located in the burn room and the corridor as shown in figure 3. Activation times for these detectors are 1isted in table 8. During the smoldering tests the corridor remained essentially smoke free and accordingly the corridor detector was not activated. It is well known that the activation time of ionization detectors is longer for smoke from smoldering fires than for flaming fires. The activation time during the three smoldering tests was in the range of 27 to 60 minutes which was considerably greater than the activation times during the flaming tests.

As expected, the activation times for the low and high energy flaming tests are for the most part in the same range as those reported by Bukowski. Test 7 is an obvious exception with an activation time of over a half hour for the corridor detector. This was because the burn room door was closed during test 7 .

\subsection{Interstitial Space Exhaust}

The purpose of exhausting the interstitial space in tests 8,9 and 12 was to prevent smoke in the interstitial space from flowing down into occupied spaces and thereby causing hazardous conditions. This is equivalent to saying that the performance of an interstitial space exhaust system should be such that it subjects the patients to no greater danger than would occur in a hospital in which the interstitial space had a solid floor. Room 2 can be considered a room in which a patient might be subject to smoke flowing through the ceiling from the interstitial space.

Workers who might be in the interstitial space at the time of a fire need to be considered. It is reasonable to expect that maintenance workers are capable of evacuating under their own power. One criteria for allowable levels of smoke obscuration and co concentration in the interstitial space is that these levels it should be no worse than they would be without an interstitial space exhaust. 
Regarding the low energy fires of tests 8 and 9, the following observations have been made in sections 5.3 and 5.5 :

(1) The interstitial space exhaust had little effect on the smoke obscuration in the interstitial space. Calculated COHb in the interstitial space was well below the critical level and the instantaneous threshold of $\mathrm{CO}$ was never reached.

(2) The optical densities in the patient rooms and in the corridor were lower with than without the interstitial space exhaust.

(3) There was no indication of smoke movement from the interstitial space into room 2 .

Therefore the interstitial space exhaust system successfully met the above requirements when it was exposed to a low energy fire in these tests.

Regarding the high energy fire of test 12, the following observations were made in sections 5.4 and 5.5 :

(1) The interstitial space exhaust had little effect on the smoke obscuration in the interstitial space. The time for calculated $\mathrm{COHb}$ to reach the critical level was essentially the same with or without the exhaust.

(2) The optical densities in the corridor and in the patient rooms were lower with than without the interstitial space exhaust.

(3) There was some slight smoke movement through the ceiling of room 2. However, the smoke obscuration was below the critical level as was the calculated $\mathrm{COHb}$. The $\mathrm{CO}$ concentrations never reached the instantaneous threshold in room 2 . 
It can not be said that the exhaust system totally satisfied the above requirements because there was some smoke movement through the ceiling during the high energy fires. However, it can be said that this smoke movement did not result in hazardous conditions in room 2 . So, it would appear that the interstitial exhaust system performed reasonably well during the high energy fire. In a real hospital where the interstitial space is larger, the result would be to dilute the smoke in the interstitial space and thus reduce the problem even further.

\subsection{Patient Room Exhaust}

During test 10 the patient room exhaust system was operating. As discussed in section 5.3.6, this exhaust reduced smoke concentration in the corridor and rooms 1 and 3. The door to room 2 was sealed and room 2 remained essentially smoke free throughout the test. This might lead someone to believe that the patient room exhaust could be used to prevent smoke movement through the interstitial space. However, such a conclusion is unjustified for reasons described below.

The pressure difference across the burn room ceiling for test 10 is shown in figure 29. The pressure in the first 5 minutes of the test indicates that the burn room was at a higher pressure than the interstitial space. This would result in smoke flowing from the burn room into the interstitial space. This positive pressure was due to the buoyancy of the gas in the burn room as can be seen from the temperature curve for this test in figure 15. After about 5 minutes the temperature in the burn room decreased. With the buoyancy forces thus decreased, the exhaust system dominated air flow across the ceiling. The negative pressure across the ceiling after 5 minutes (figure 29) indicates flow from the interstitial space into the burn room. Therefore, except for the first 5 minutes of this test, no smoke flowed into the interstitial space. Without similar pressures in room 2, air must have been pulled by the exhaust fan from the interstitial space into room 2 . The fact that there was so little smoke in the interstitial space explains why room 2 remained essentially smoke free during test 10 . 
Unfortunately the exhaust system could not be tested during a high energy fire due to temperature limitations of the fan. This would not necessarily be the case for real buildings where exhaust fans serving larger areas would be subjected to lower temperatures due to dilution. However, observation of the results of the high energy tests can yield insight into what would happen if a high energy fire was exhausted. It was seen in the first few minutes of test 10 that temperatures of $100^{\circ} \mathrm{C}$ in the burn room forced smoke into the interstitial space in spite of the inhibiting effect of the patient room exhaust system. The higher temperatures from the high energy tests (figures 25 and 26) would result in much more smoke being forced into the interstitial space over a longer period of time. In such a situation, the exhaust system would pull this same smoke from the interstitial space into room 2. Therefore, it can be concluded that if the conditions of test 10 were repeated for a high energy fire, significant levels of smoke would have accumulated in room 2. These resulting room 2 concentrations would be even higher in the case of a longer duration fire, which is frequently the case in real buildings.

\subsection{Smoke Movement Paths}

During this test series there was smoke movement through (1) open doorways, (2) the crack under the doors, (3) the exhaust duct system, and (4) the cracks in the ceiling system. During all high energy tests and low energy tests except for test 7 , there was considerable smoke movement through the open burn room door into the corridor and from the corridor into rooms 1 and 3 through open doors. During these tests the smoke obscuration in the corridor and in rooms 1 and 3 were all in the same range and were considerably higher than the smoke obscuration in the interstitial space or in room 2. As one might expect, this indicates that the smoke movement through the open doors is greater than that through other paths mentioned above. 
During the smoldering tests, small quantities of smoke were observed leaking through the crack under the closed burn room door and into the corridor. However, the resulting smoke obscuration in the corridor was negligible. During tests 5, 6, and 8 smoke was observed flowing from the corridor into room 2 through the crack under the door to room 2 . Although, this was the only observed path of smoke movement into room 2 during these tests, and the resulting smoke obscurations in room 2 were significant. For test 9 the cracks around the door to room 2 were sealed, and smoke was observed flowing into room 2 through the exhaust duct (exhaust system not operating). The resulting smoke obscuration in room 2 was considerably lower during this test than when the door was not sealed. The leakage through the exhaust duct system was less than that through the crack under the door to room 2. A similar leakage was observed through the exhaust duct system during high energy fire of test 11 .

For test 12, the supply register and the exhaust grill were sealed in room 2. Smoke traces were observed around the ceiling tile near the supply register after test 12. These traces indicated that there was some smoke movement through the ceiling system, however it could not be determined whether this smoke movement was into or out of room 2. The smóke obscuration in room 2 during test 12 was quite 1ow. This indicates that any leakage that might have occurred from the interstitial space into room 2 through the ceiling system would have been much less that that through the other smoke movement paths discussed.

\section{SUMMARY AND CONCLUSIONS}

1. The use of the interstitial space exhaust at a rate of two air changes per hour as described in this test series will effectively prevent hazard conditions due to smoke downflow through the suspended ceiling from the interstitial space during low or high energy fires represented in this test series. This is discussed in detail in section 5.6 . 
2. There was an indication of smoke leakage through the ceiling of room 2 during test 12, a high energy test. While the direction of the leakage was not determined, it is possible that smoke was leaking into room 2 from the interstitial space. Hazard conditions in room 2 due to smoke obscuration or due to co concentrations did not result. It can be further stated that this leakage was considerably less than leakages observed through open doorways, through cracks under closed doors, and through the exhaust duct system. This is discussed in section 5.8 .

3. Smoldering fires of the type examined in this test series are not a significant problem in hospitals. This is discussed in section 5.2 .

4. When the ceiling system was not subjected to high temperatures, the most significant smoke leakage into the interstitial space was observed flowing through the crack between the wall and the wall molding of the ceiling suspension system. This was observed in the smoke candle test and during the first 4 minutes of tests 11 and 12. This leakage existed in spite of the fact that this crack was filled with an open cell foam.

5. When the ceiling system was exposed to high temperatures the metal grid system warped and greatly increased the smoke flow through the ceiling. This is discussed in detail in section 5.4.3.

6. The use of the fire retardant blanket (matrix fiber of 50 percent vinyl and 50 percent vinyon) on the bed fire of test 4 resulted in significantly lower temperature and smoke production than the use of a cotton blanket on the bed fire. This is discussed in section 5.3 .1 . 
7. The use of the patient room exhaust air system reduced smoke concentration throughout the test facility in test 10 as discussed in section 5.3.6. During this low energy fire room 2 was virtually smoke free. However, in the event of a high energy fire significant smoke levels in room 2 would probably result even with this exhaust system. The reasons for this statement are discussed in section 5.7 .

8. Closing the burn room door for the low energy fire of test 7 resulted in higher $\mathrm{CO}$ concentrations in the burn room. Test 7 was the only low energy test where critical levels of calculated COHb were reached in the burn room. However, closing the burn room door did result in lower smoke obscuration and CO concentrations outside the burner room. This is discussed in section 5.3.6.

9. The movement of smoke produced by a smoke candle is considerably different than the movement of smoke from a flaming or smoldering fire. This is discussed in section 5.5.1.

10. The activation times of the ionizing smoke detectors during flaming tests were found to be consistent with previous work. This is discussed in section 5.5.3.

\section{ACKNOWLEDGEMENTS}

Appreciation is expressed to Lionel Issen and William Bailey for their contributions to the design and construction of the test facility. Appreciation is also expressed to Warren Hayes, Richard Zile and Melvin Womble for instrumentating of the test facility and conducting the experiments. The author is especially appreciative of Warren Hayes for his effort in developing a highly reproducible smoldering fire. Thanks are due to Richard Peacock who wrote the computer graphics 
routine used to generate the graphs in this paper. Thanks are also due to Sandra Nowstrup for using that routine to generate those graphs. Special thanks are due to Emil Braun who wrote the computer routines used for data acquisition and data reduction.

\section{REFERENCES}

[1] Fire Resistance Directory, Underwriters Laboratory (Jan. 1980).

[2] McCaffrey, B. J. and Heskestad, G., A Robust Bidirectional Low Velocity Probe for Flame and Fire Application, Combustion and Flame, Vol. 26, 125-7, (1976).

[3] Babrauskas, V., Combustion of Mattresses Exposed to Flaming Ignition Sources, Part 1 Full-Scale Tests and Hazard Analysis, Nat. Bur. Stand. (U.S.), NBSIR 77-1290, (Sept. 1977).

[4] O'Neil1, J. G. and Hayes, W. D., Ful1-Scale Fire Tests with Automatic Sprinklers in a Patient Room, Nat. Bur. Stand. (U.S.), NBSIR 79-1749, (June 1979).

[5] 0'Neill, J. G. and Hayes, W. D., Full-Scale Fire Tests with Automatic Sprinklers in a Patient Room - Part II, Nat. Bur. Stand. (U.S.), NBSIR 80-2097, (July 1980).

[6] Jin, T., Visibility through Fire Smoke, Part 2, Report of the Fire Research Institute of Japan, No. 33, 31-48 (1971). Part 5, Report of Fire Research Institute of Japan, No. 42, 12-18 (1975).

[7] Jin, T., Visibility through Fire Smoke, Main Reports on Production, Movement and Control of Smoke in Buildings, pp. 100-153, Japanese Association of Fire Science and Engineering (1974). 
[8] Steward, R. D., et a1, Experimental Human Exposure to High Concentrations of Carbon Monoxide, Architectural Environmental Health, Vo1. 26, 1-7 (Jan. 1973).

[9] Parker, J. E., Jr. and West, V. R., Bioastronautics Data Book, NASA SP-3006, Chapter II, Scientific and Technical Information office, NASA (1973).

[10] Alarie, Y. and Zullo, P., Predicting Carboxyhemoglobin for Different Patterns of Carbon Monoxide Exposure, Industrial Health Foundation Symposium on Carbon Monoxide, pp 18-46, Pittsburgh, Pa (1974).

[11] Kimmerle, G., Aspects and Methodology for the Evaluation of Toxicological Parameters during Fire Exposure, Journal of Fire and Flammability/Combustion Toxicology, Vo1. 1, 4-41 (Feb. 1974).

[12] Stewart, R. D., The Effect of Carbon Monoxide on Man, Journal of Fire and Flammability/Combustion Toxicology, Vol. 1, 167-176 (1974).

[13] Claudy, W. D., Respiratory Hazards of the Fire Service, National Fire Protection Assn., Boston, MA (1957).

[14] Bukowski, R. W., Tests on the Performance of Automatic Fire Detectors in Health Care Occupancies - A Preliminary Report, Nat. Bur. Stand. (U.S.), NBSIR 79-1739 (April 1979). 


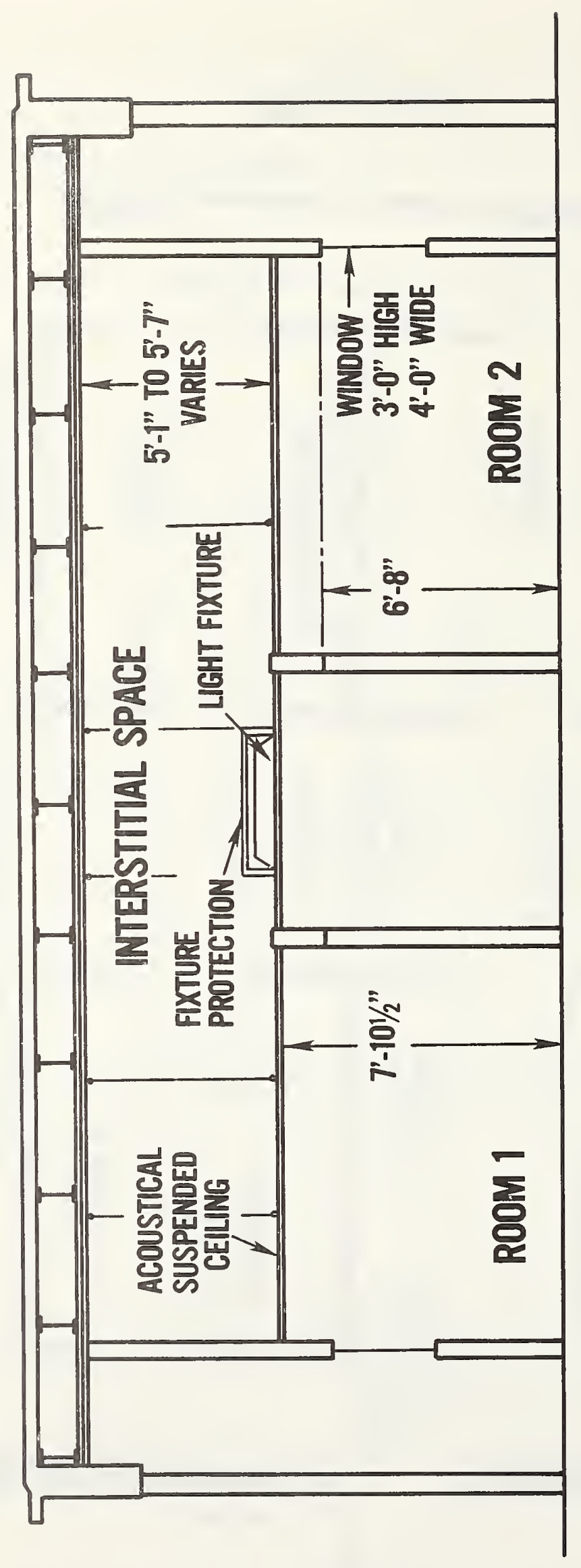

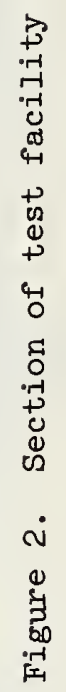




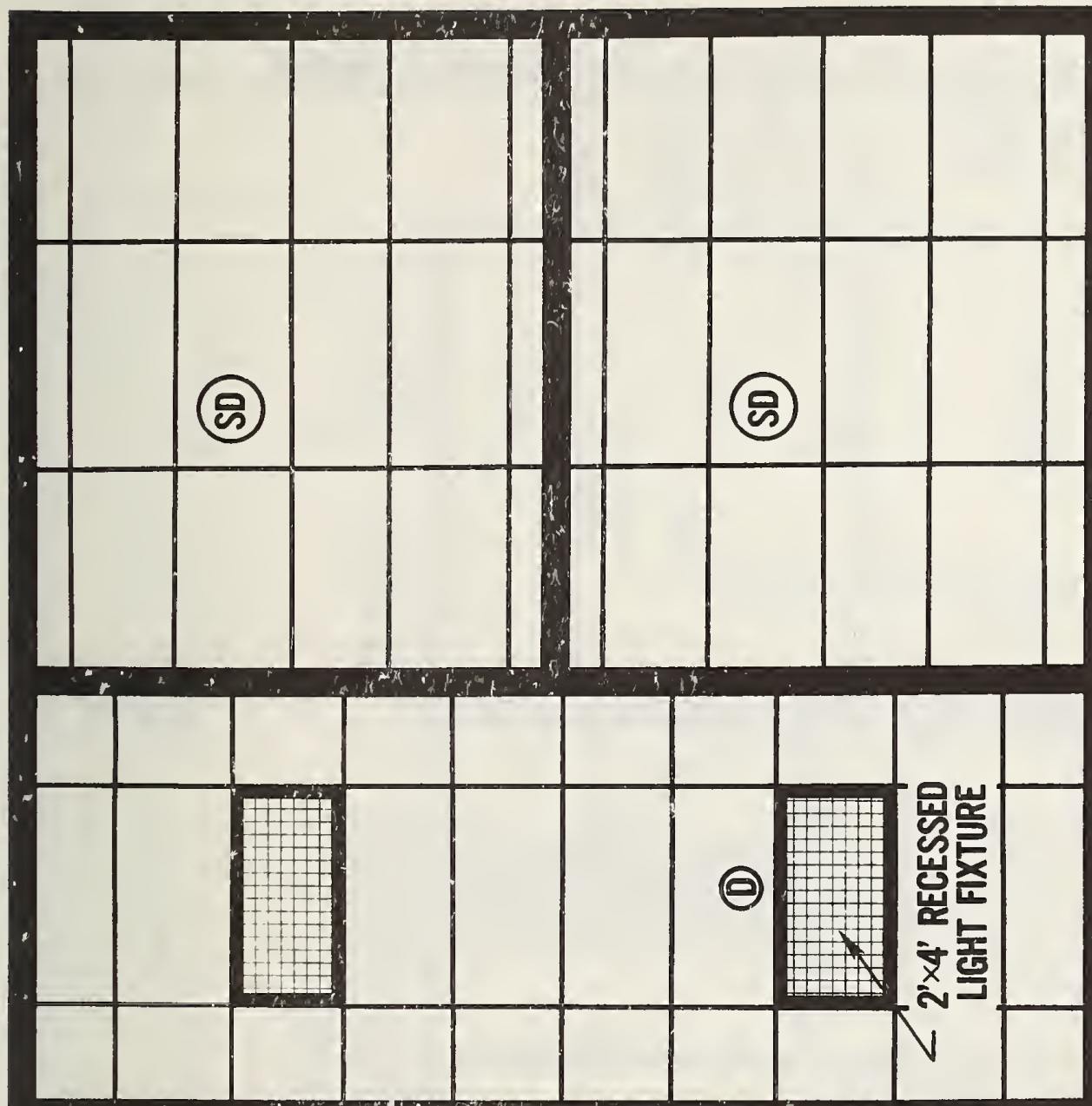

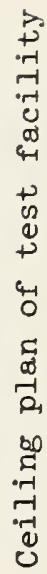

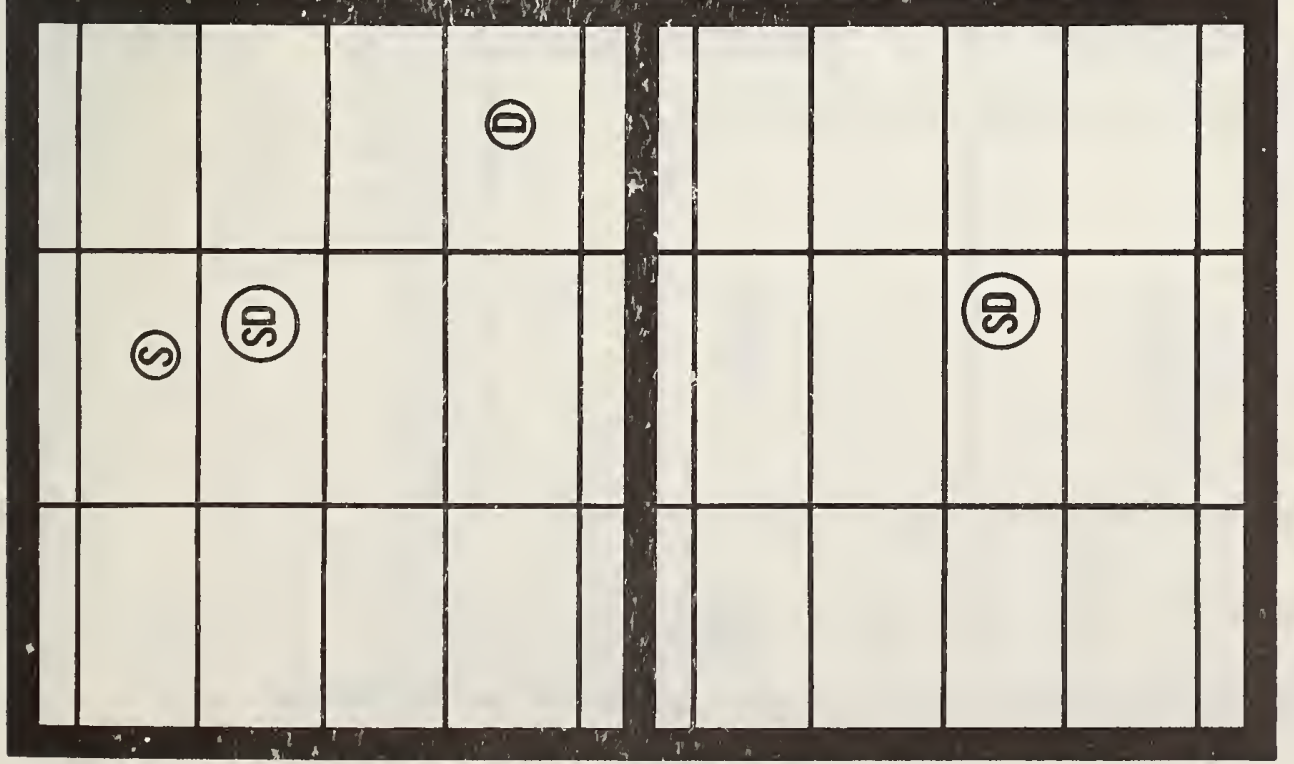

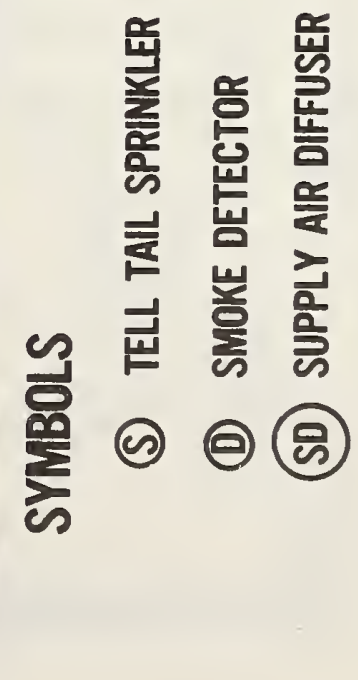




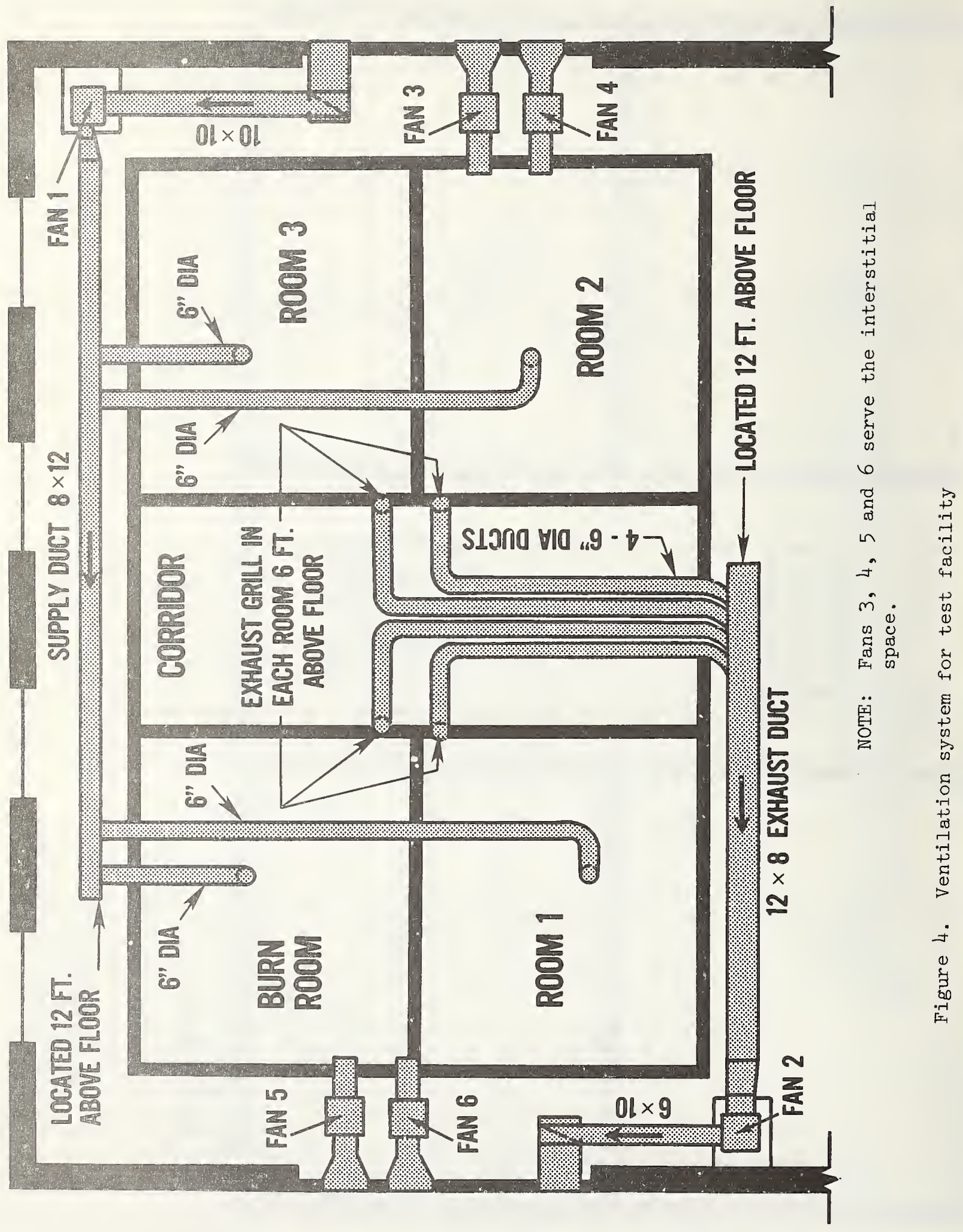




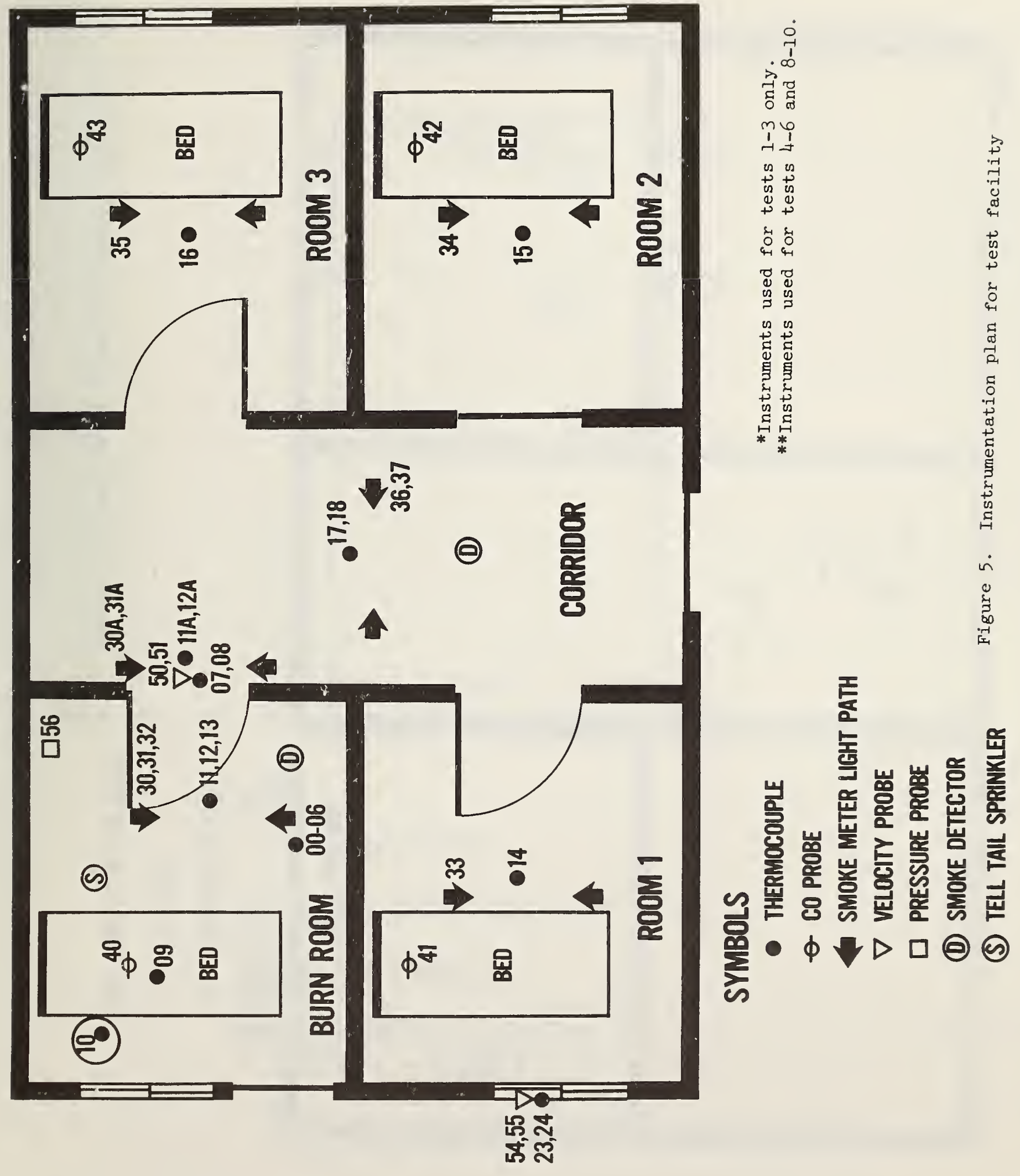




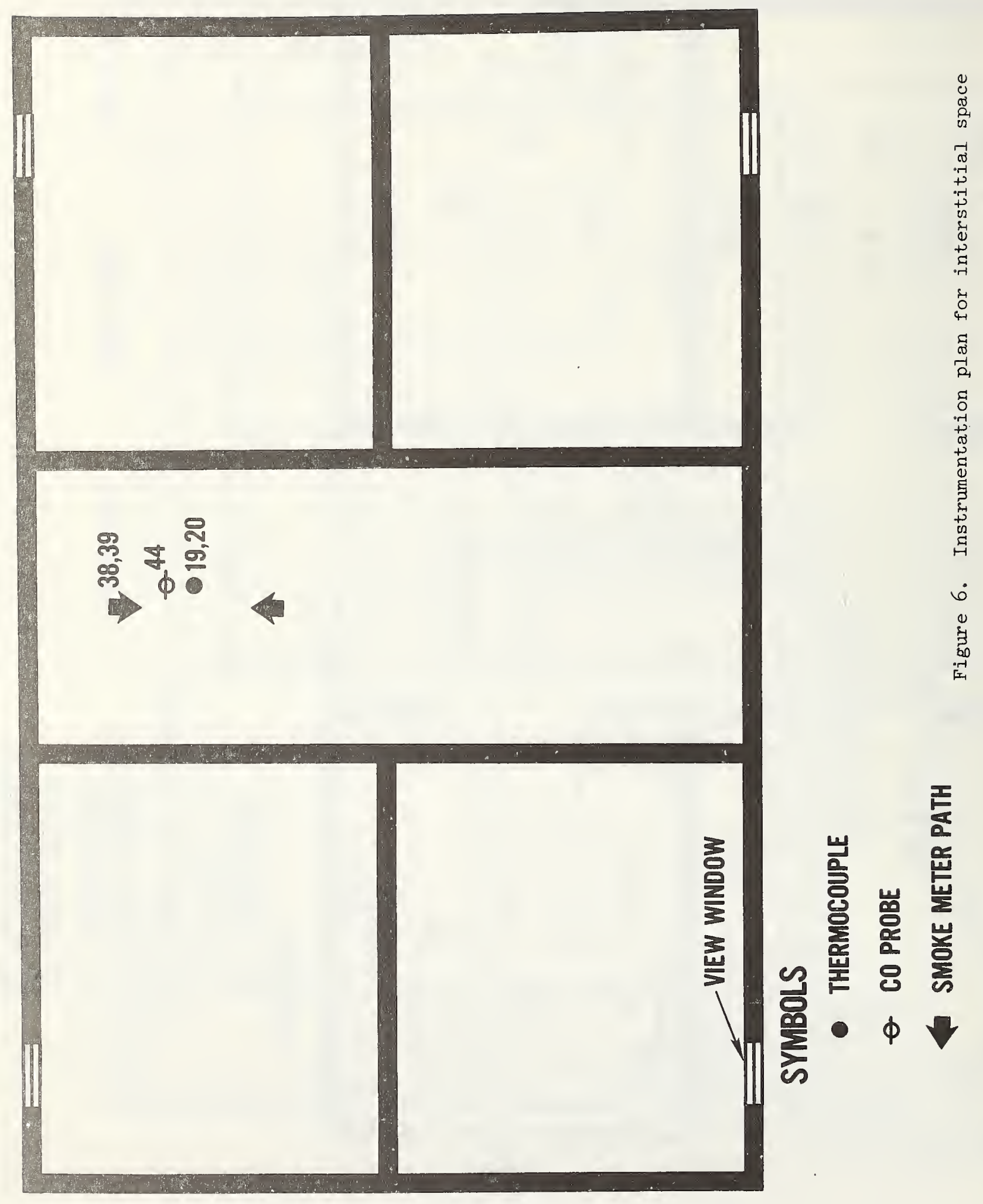




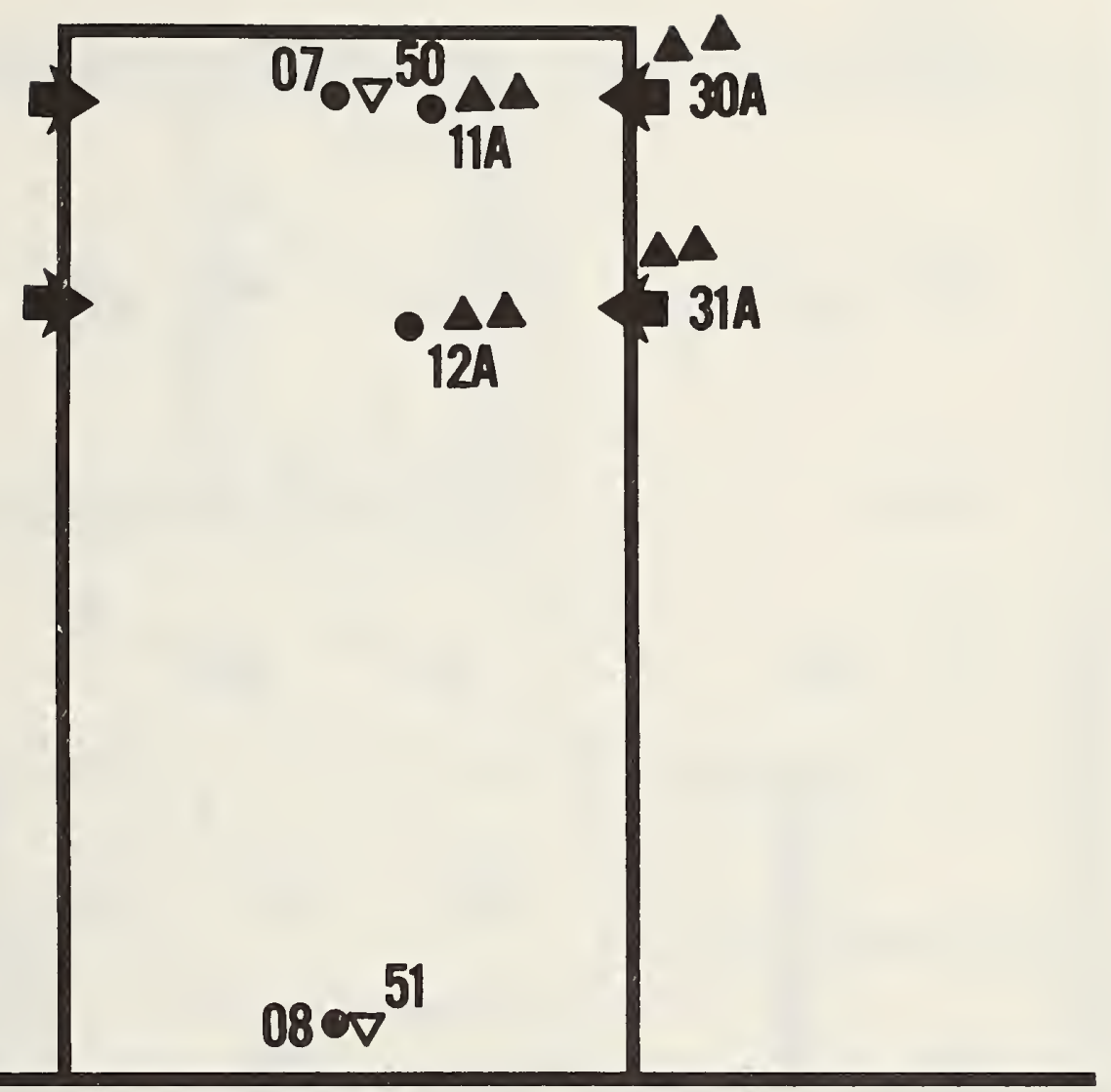

\section{SYMBOLS}

- THERMOCOUPLE

SMOKE METER LIGHT PATH

$\nabla$ VELOCITY PROBE

$\triangle \triangle$ INSTRUMENTS USED FOR

TESTS 4 - 6 AND 8 - 10 
$56 \square$

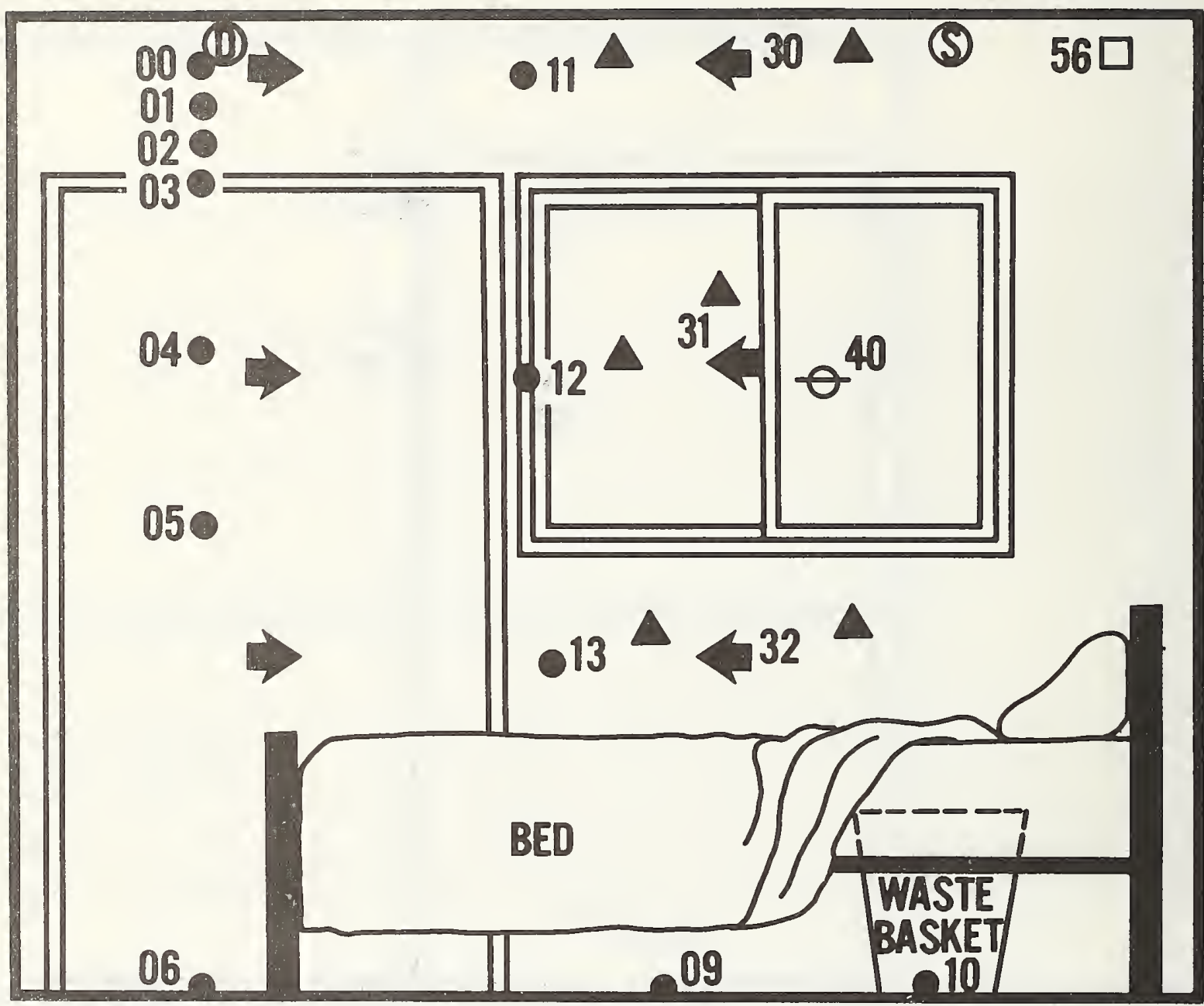

SYMBOLS

- THERMOCOUPLE

$\theta$ CO PROBE

$\triangle$ SMOKE METER PATH

口 PRESSURE PROBE

(II) SMOKE DETECTOR

(S) TELL TAIL SPRINKLER

$\triangle$ INSTRUMENTS USED FOR TESTS 1-3 ONLY 


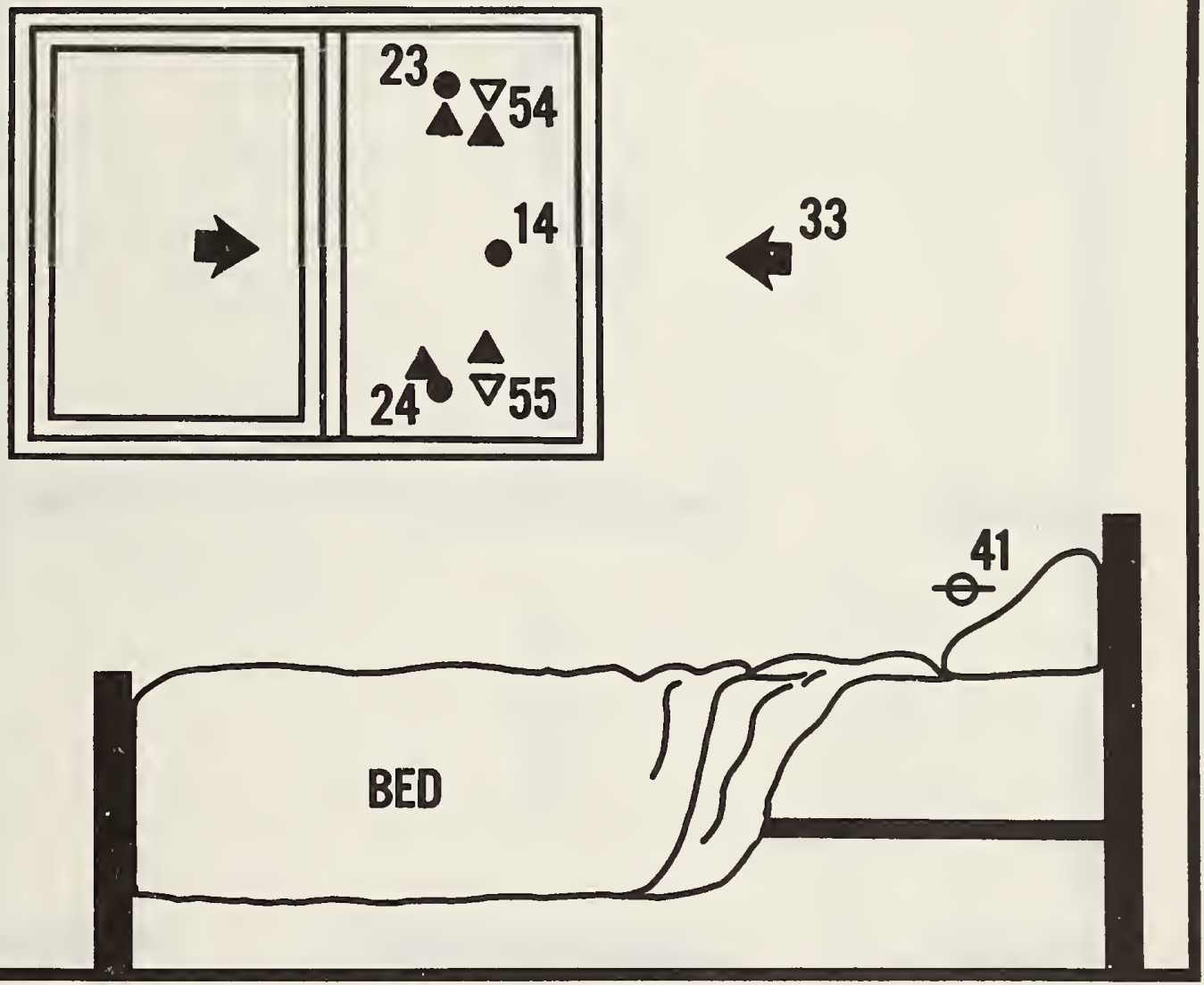

SYMBOLS

- THERMOCOUPLE

$\theta$ CO PROBE

SMOKE METER LIGHT PATH

$\nabla$ VELOCITY PROBE

$\triangle$ INSTRUMENTS USED FOR TESTS 1-3 ONLY
NOTES:

1. Room 2 window was open for tests $1-3$ only. All other windows were closed throughout the test series.

2. Heights of smoke meter,

thermocouple and $\mathrm{CO}$ probe in rooms 2 and 3 are the same as for room 1 .

Figure 9. Instrumentation in room 1 


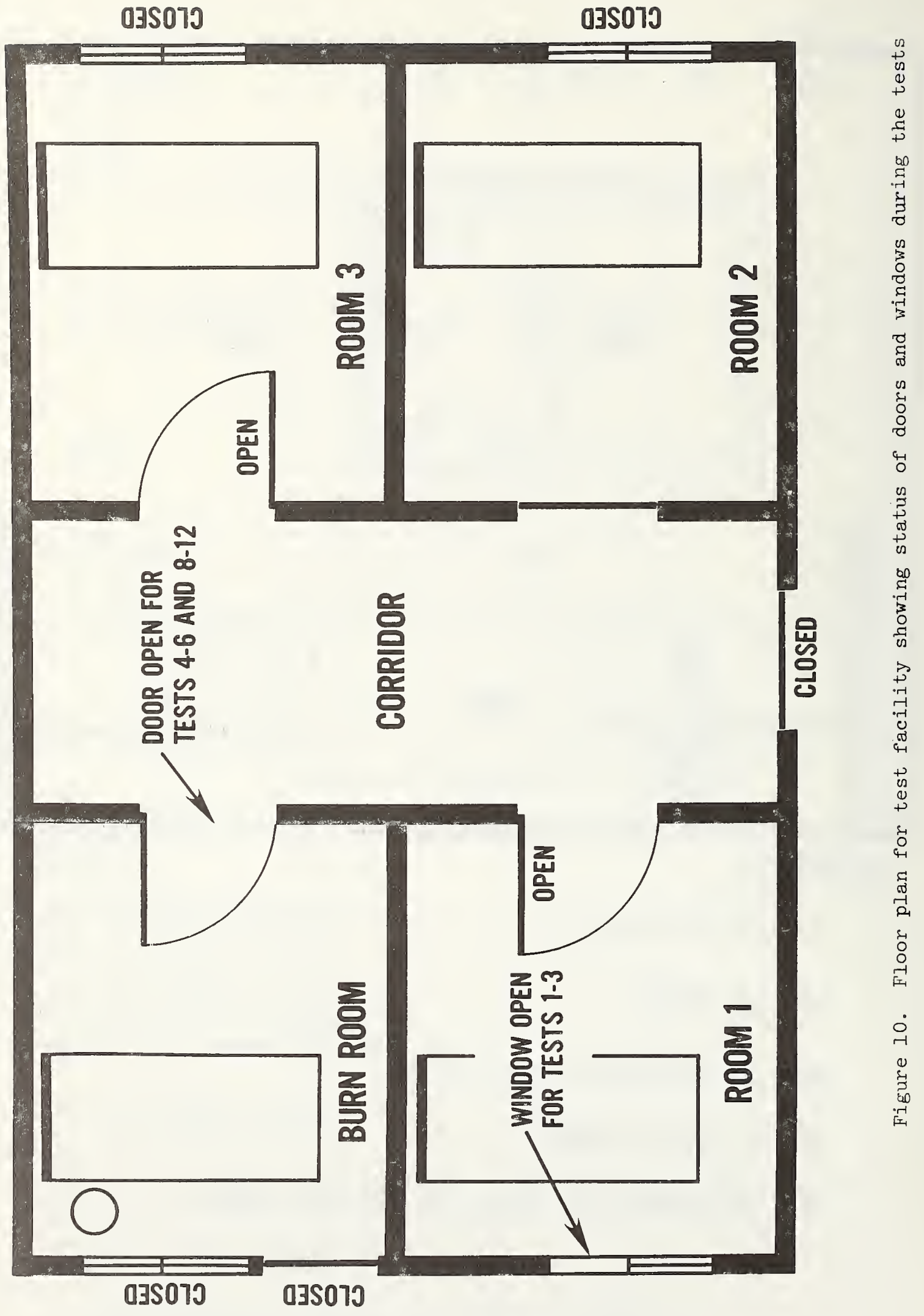




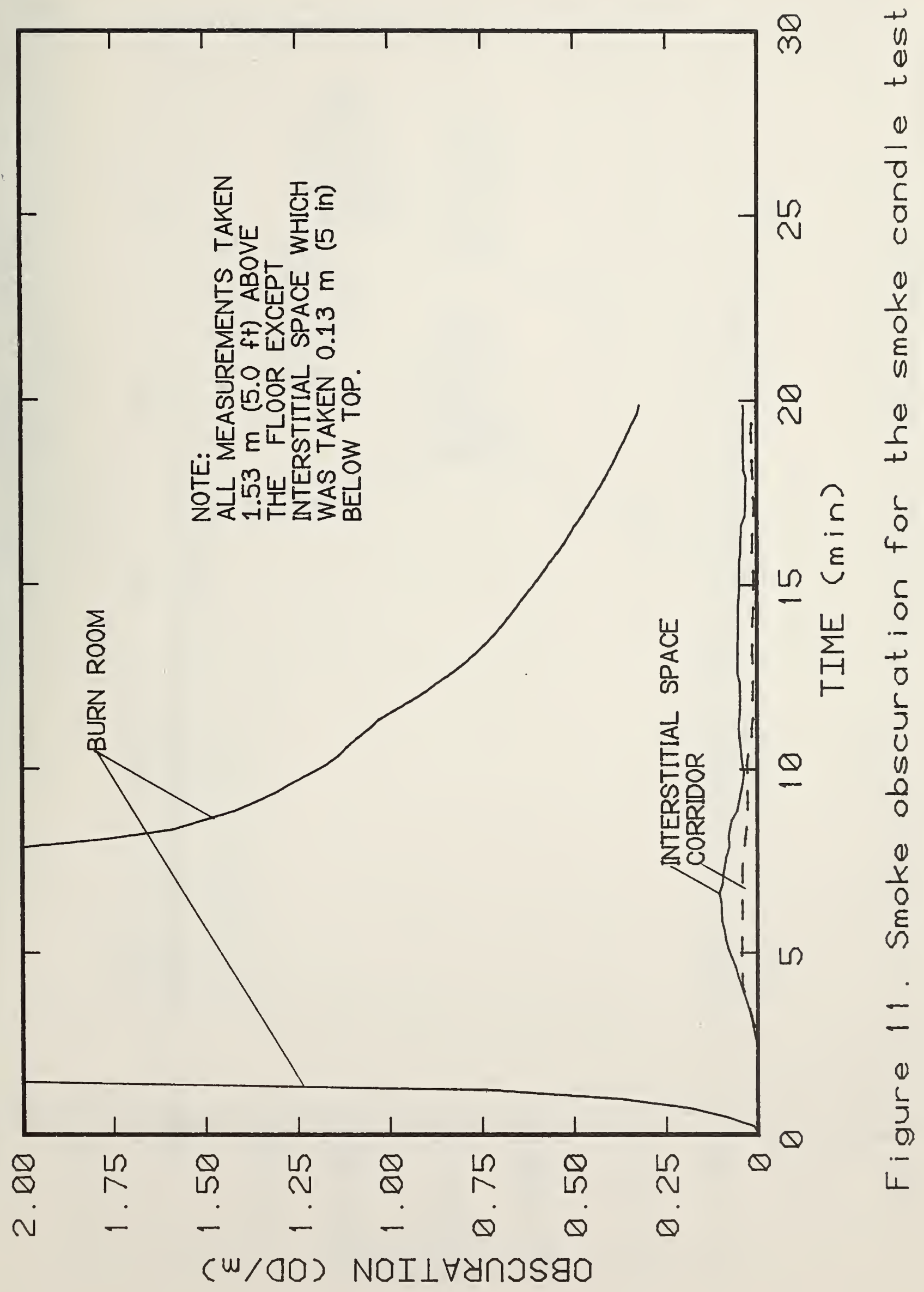




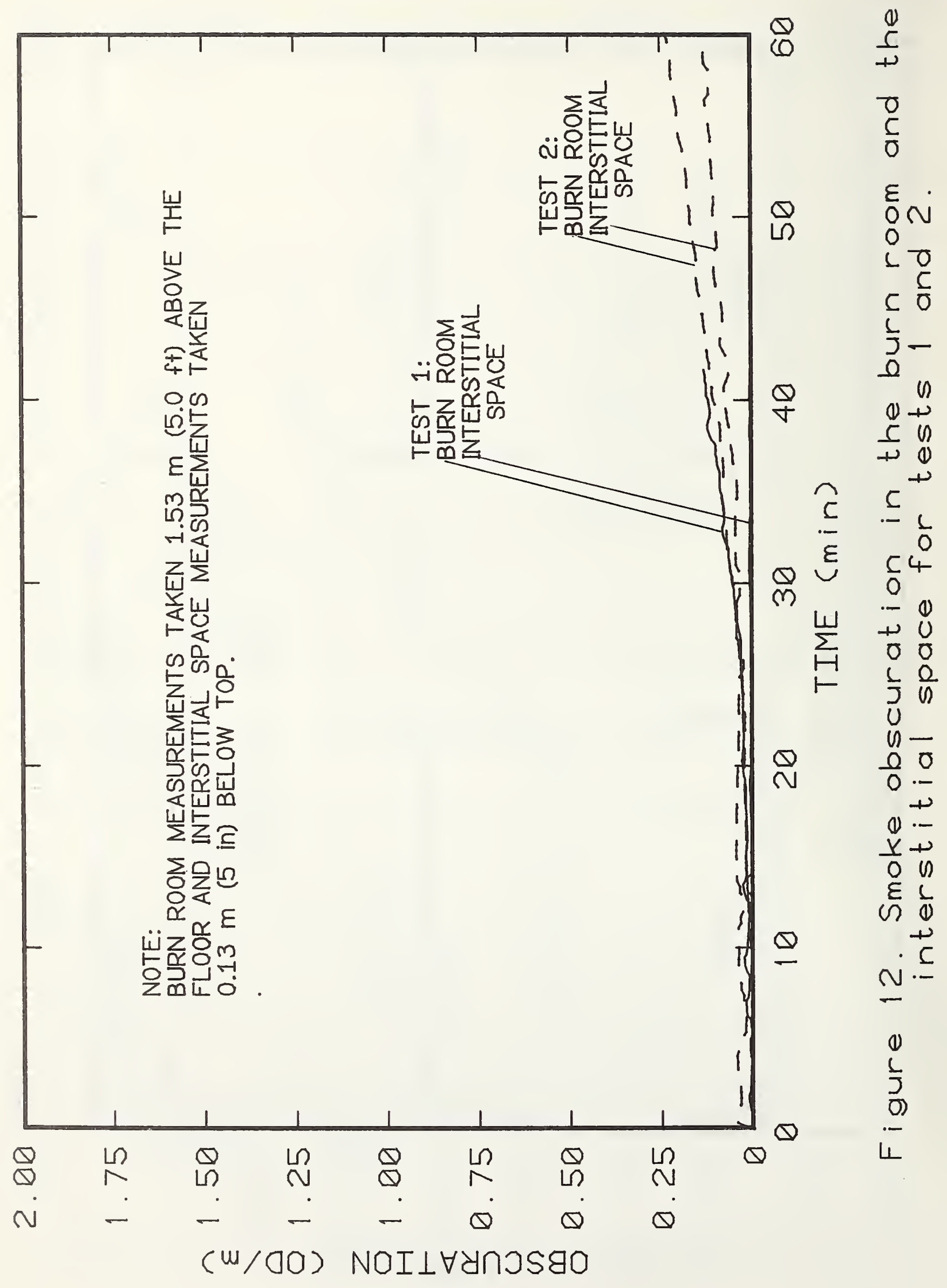




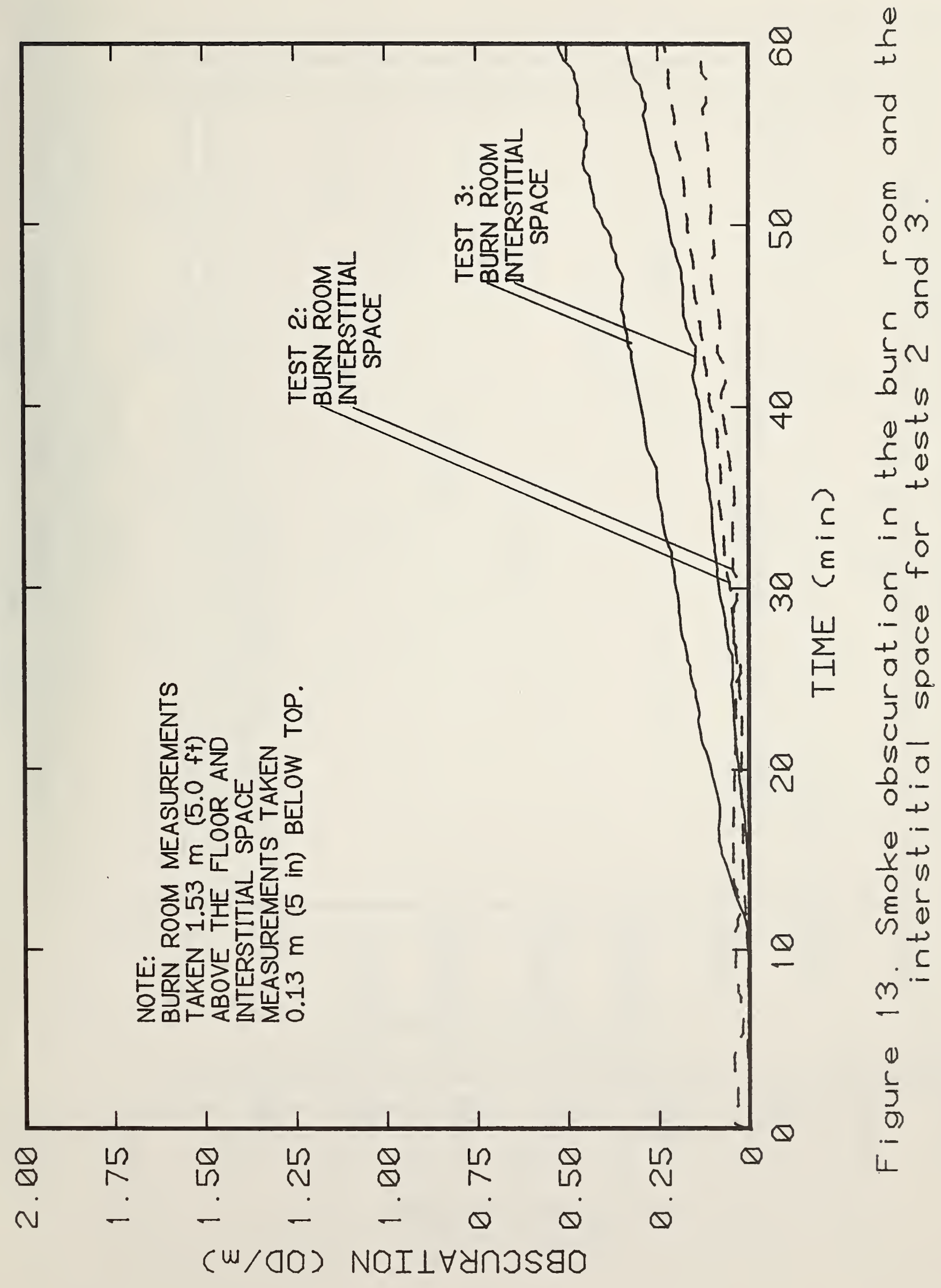




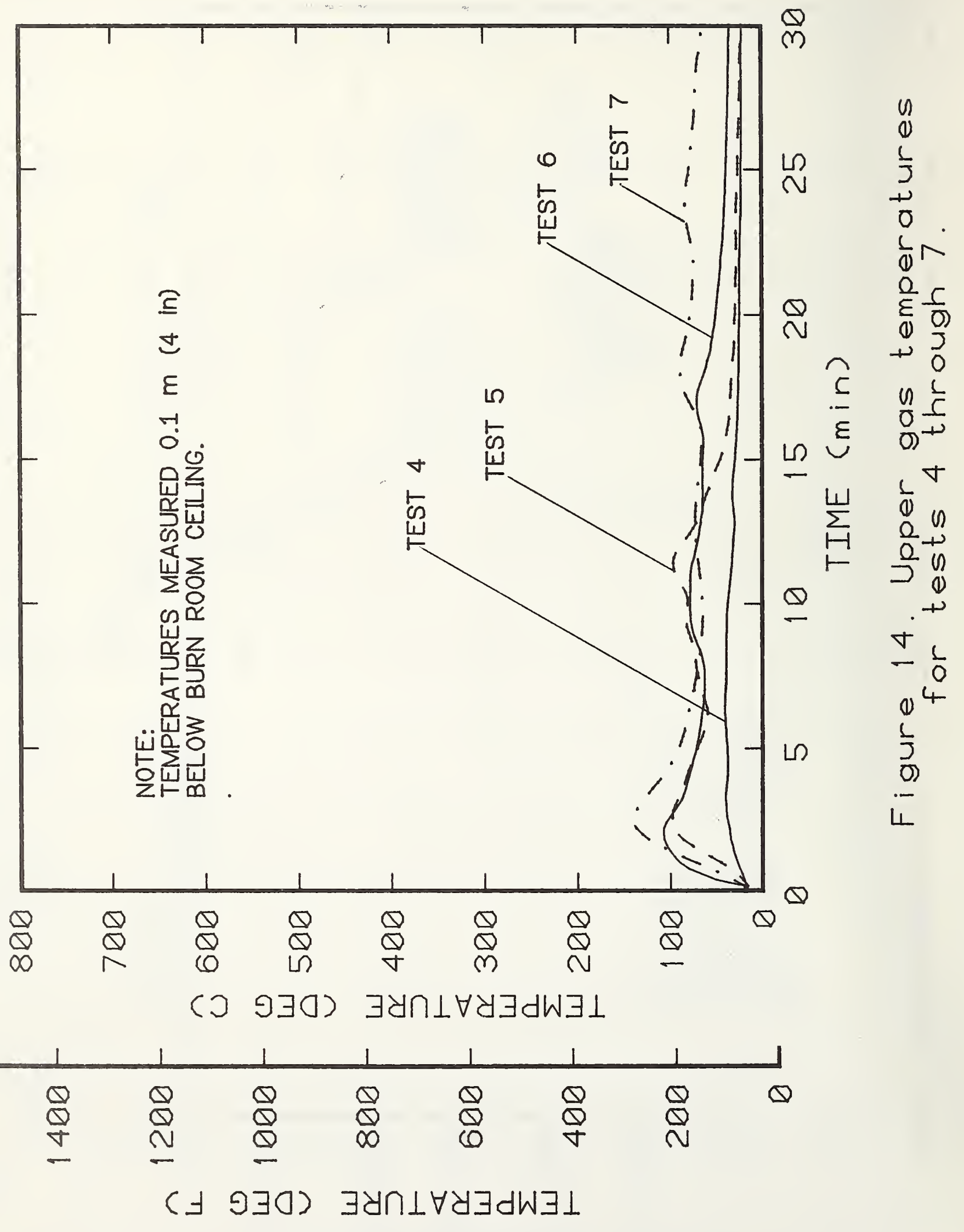




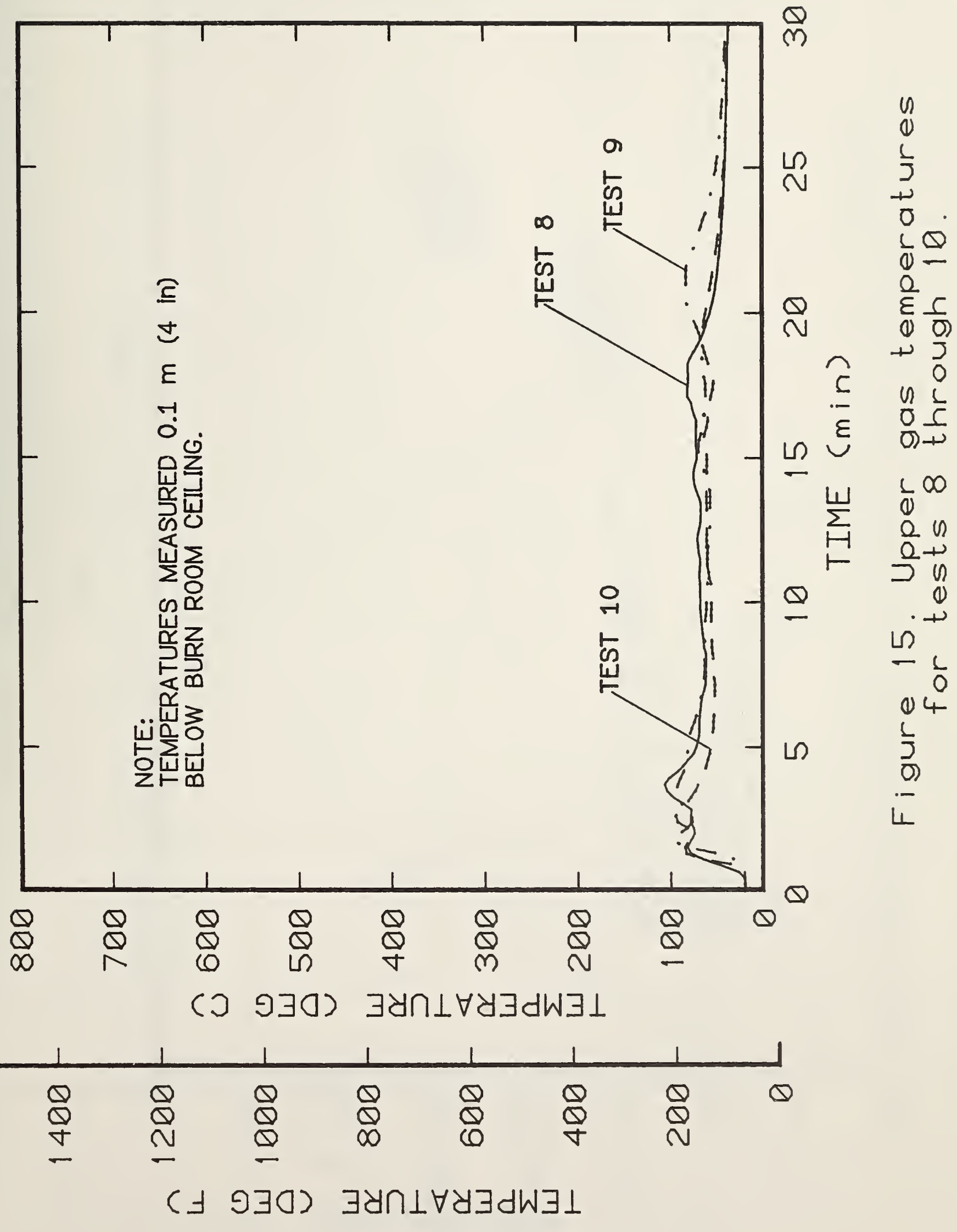




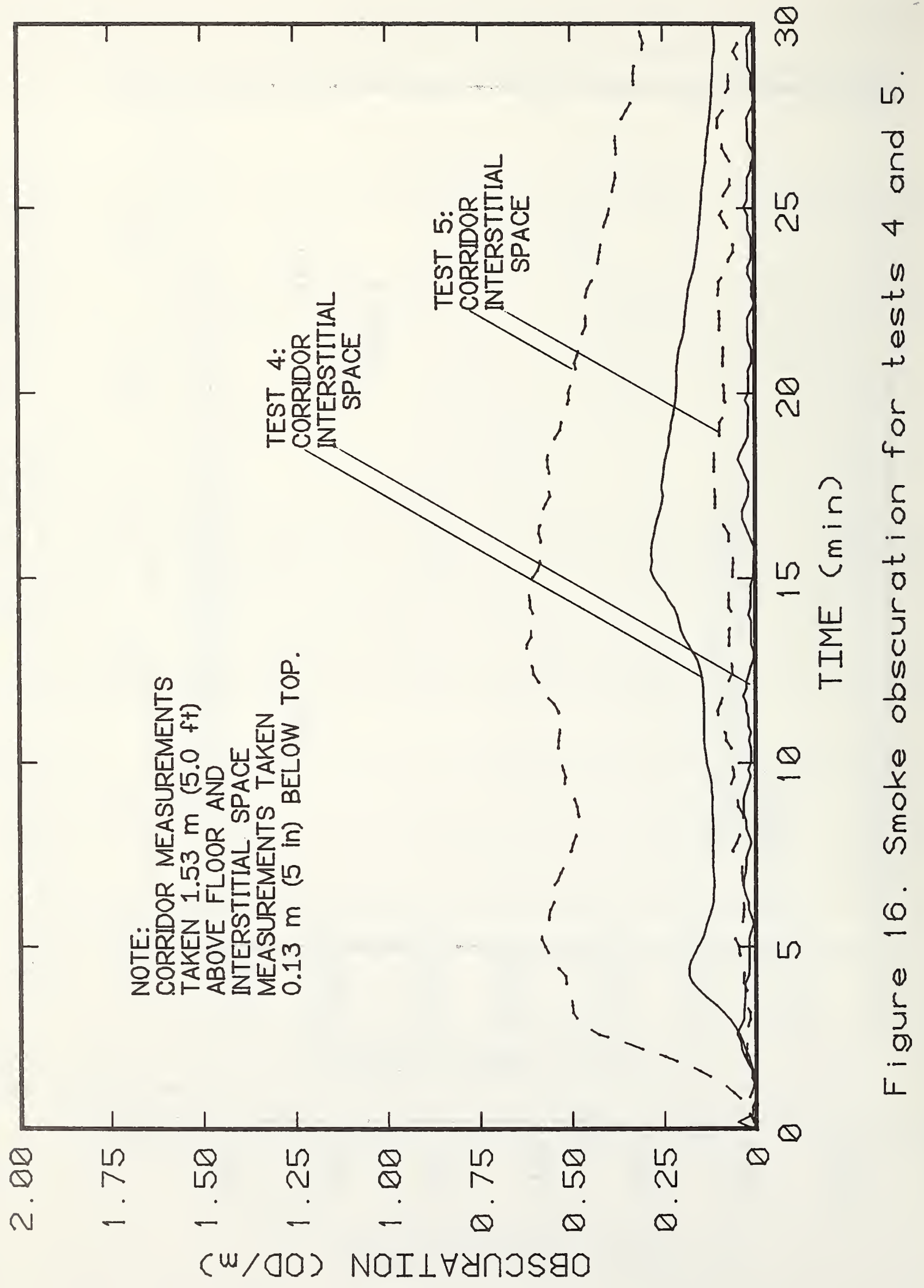




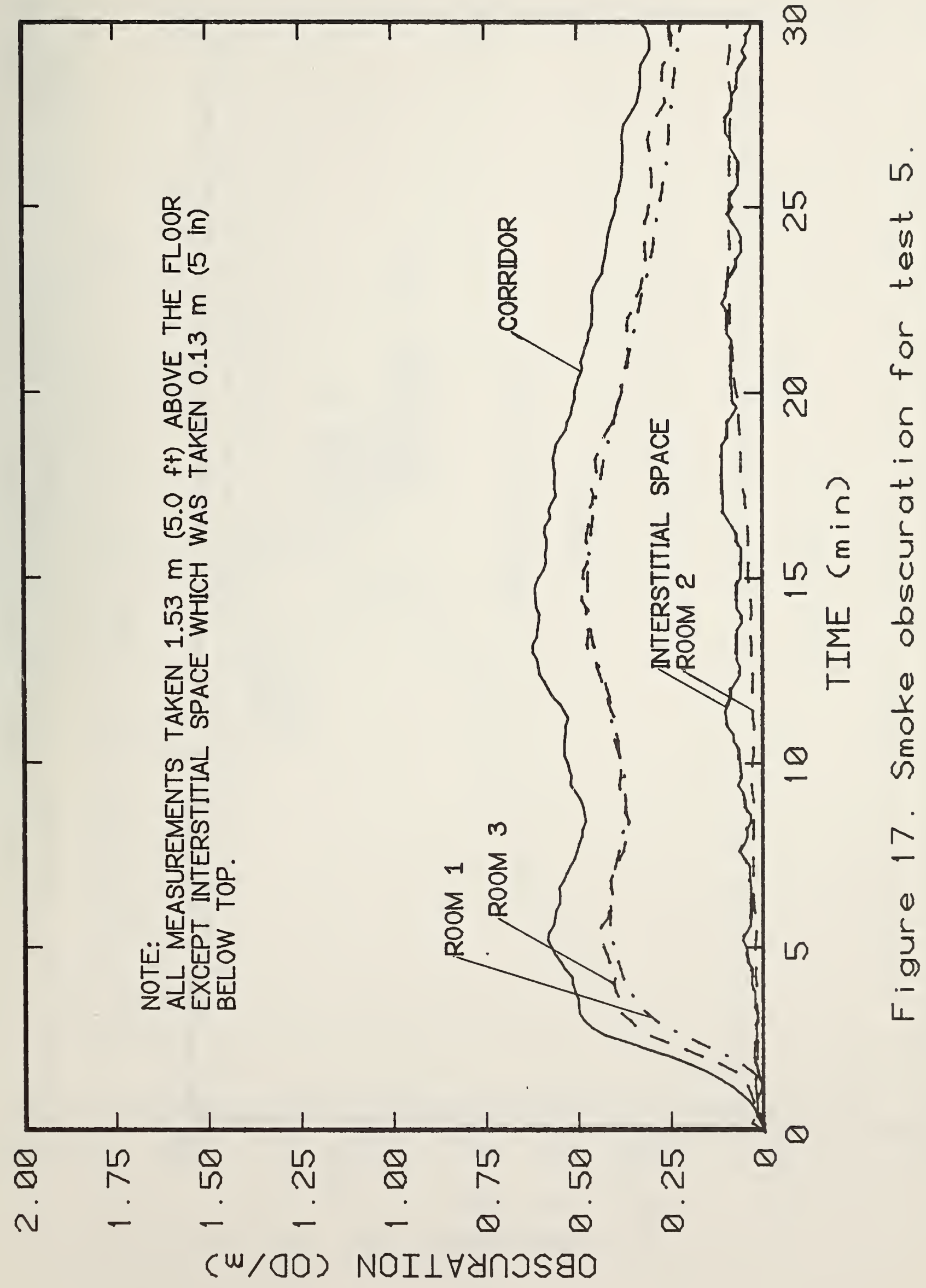




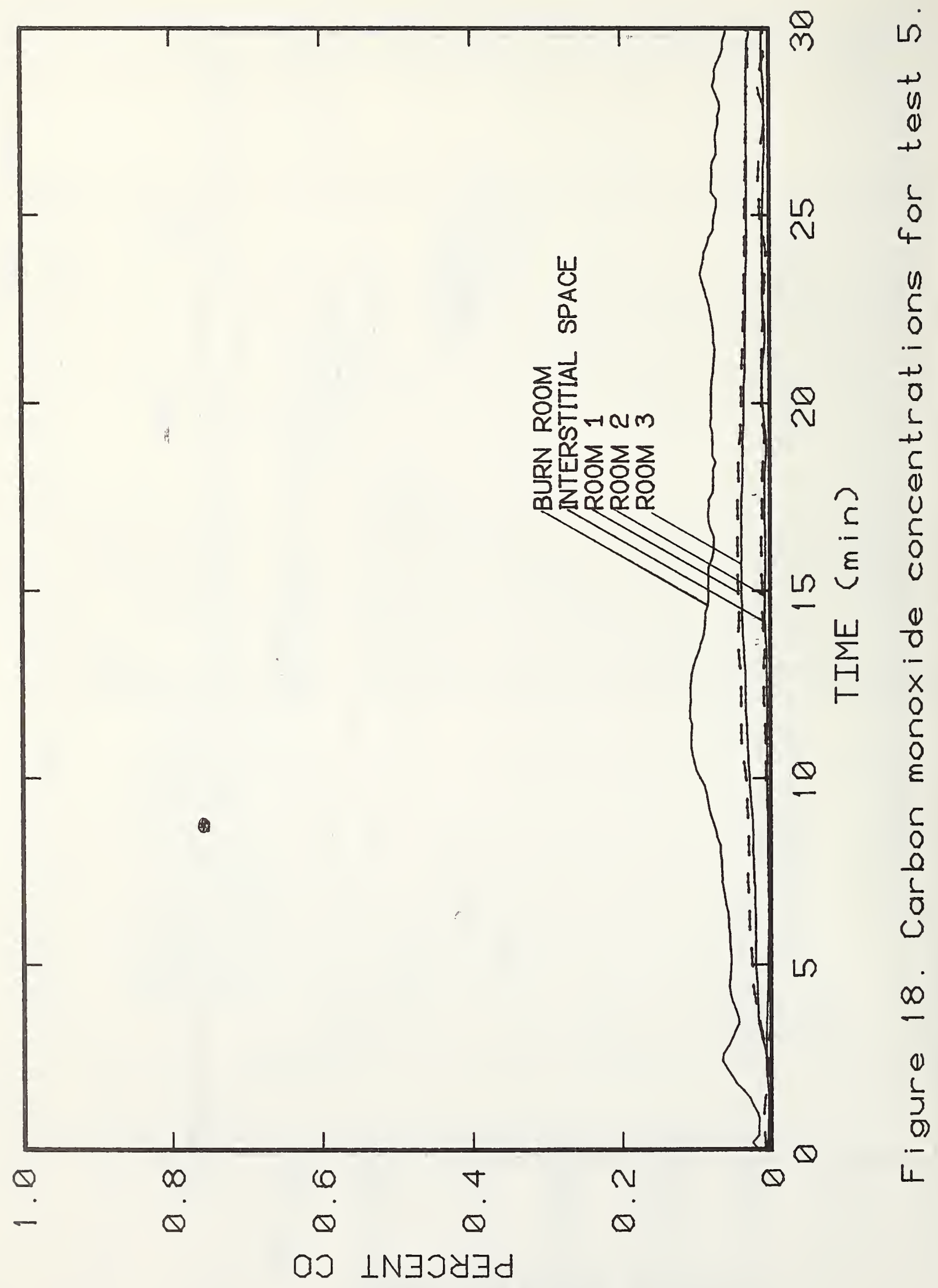




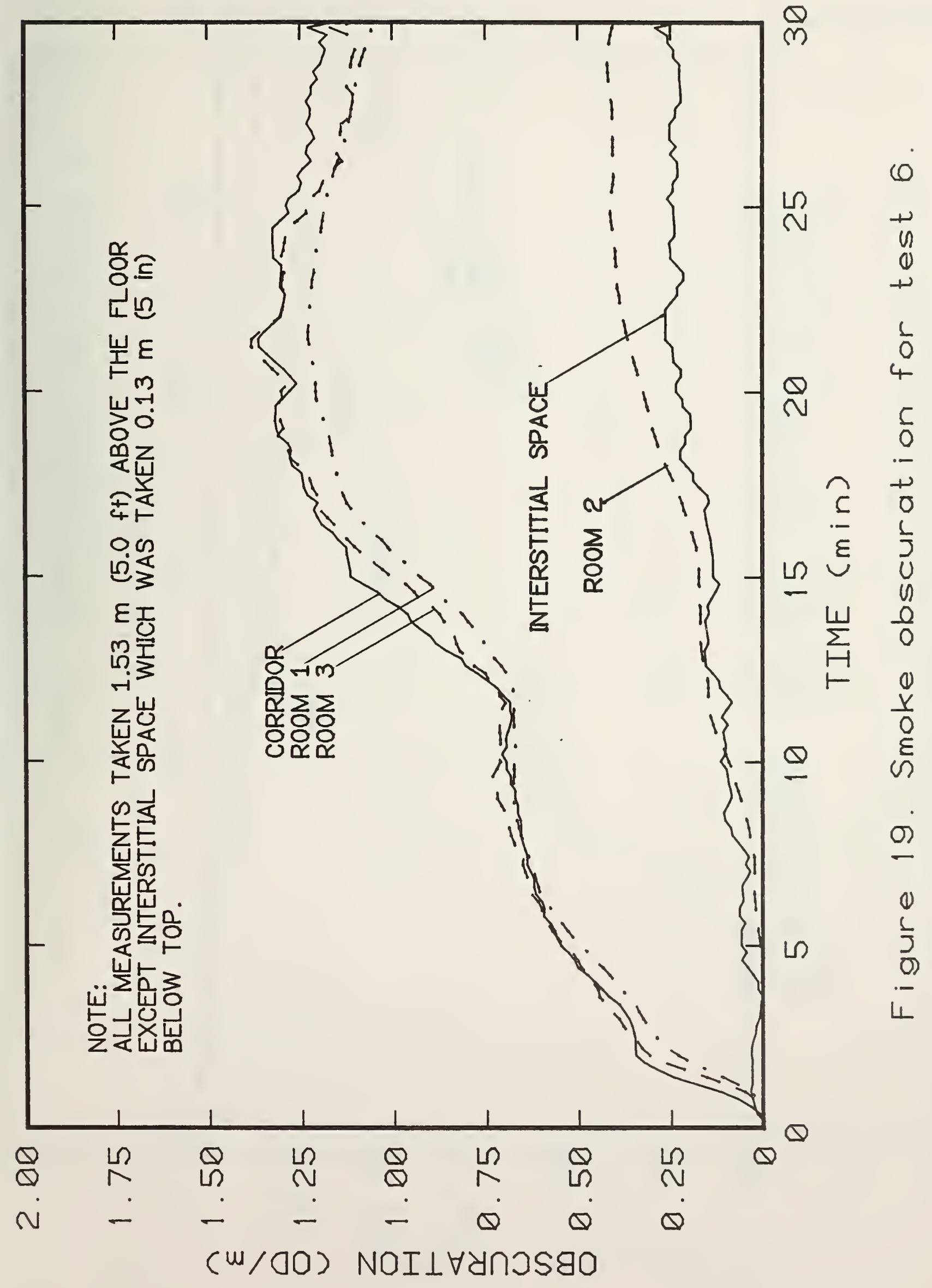




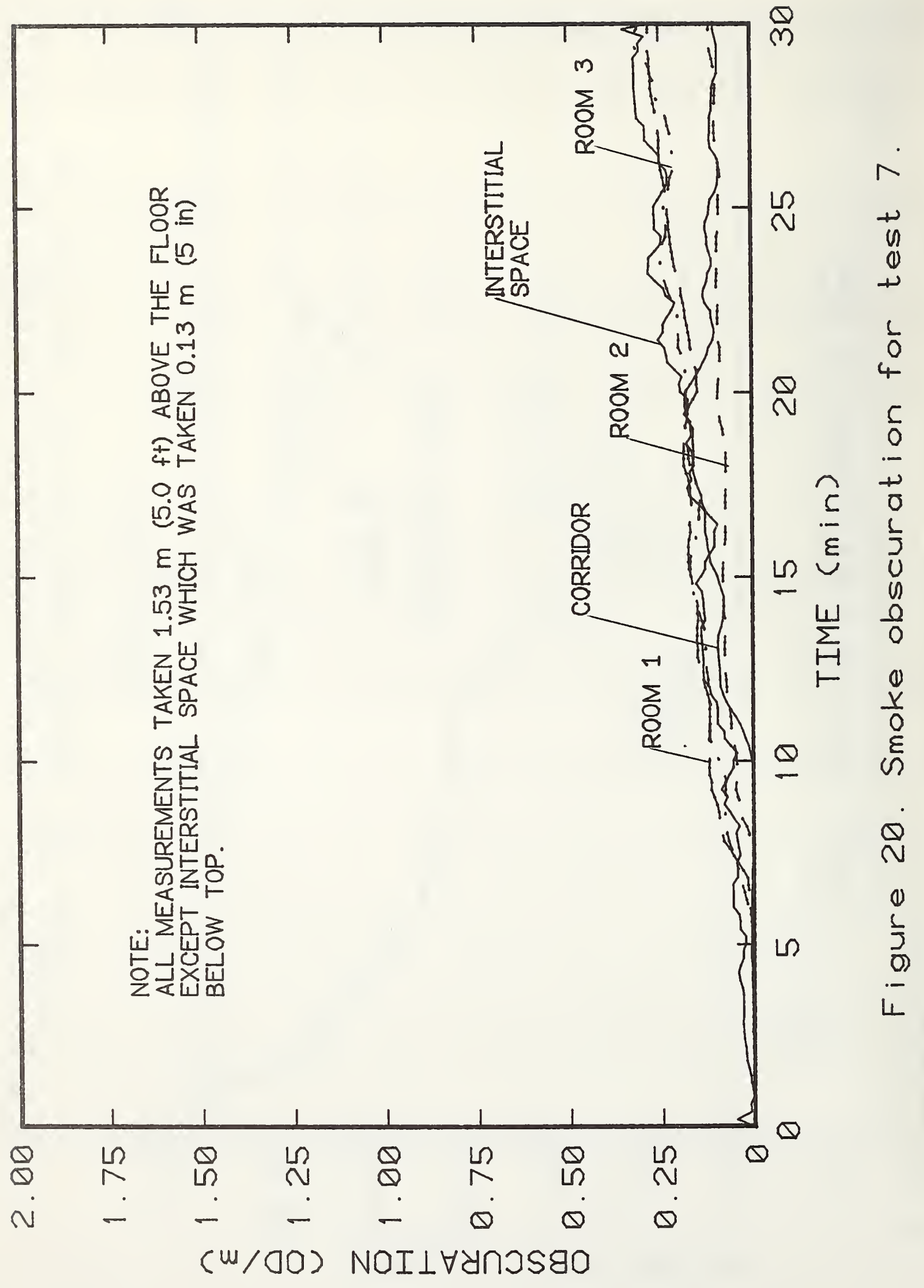




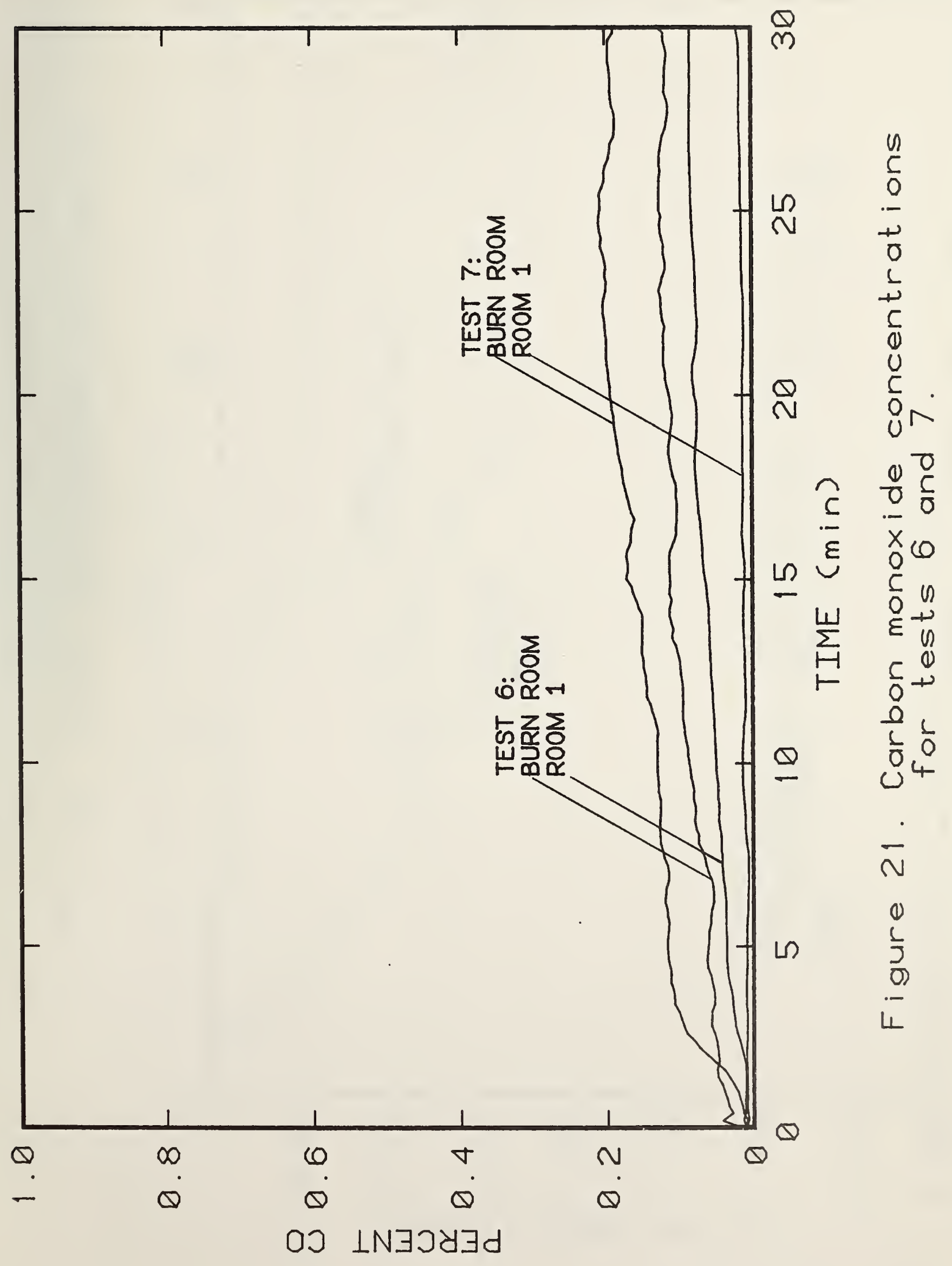




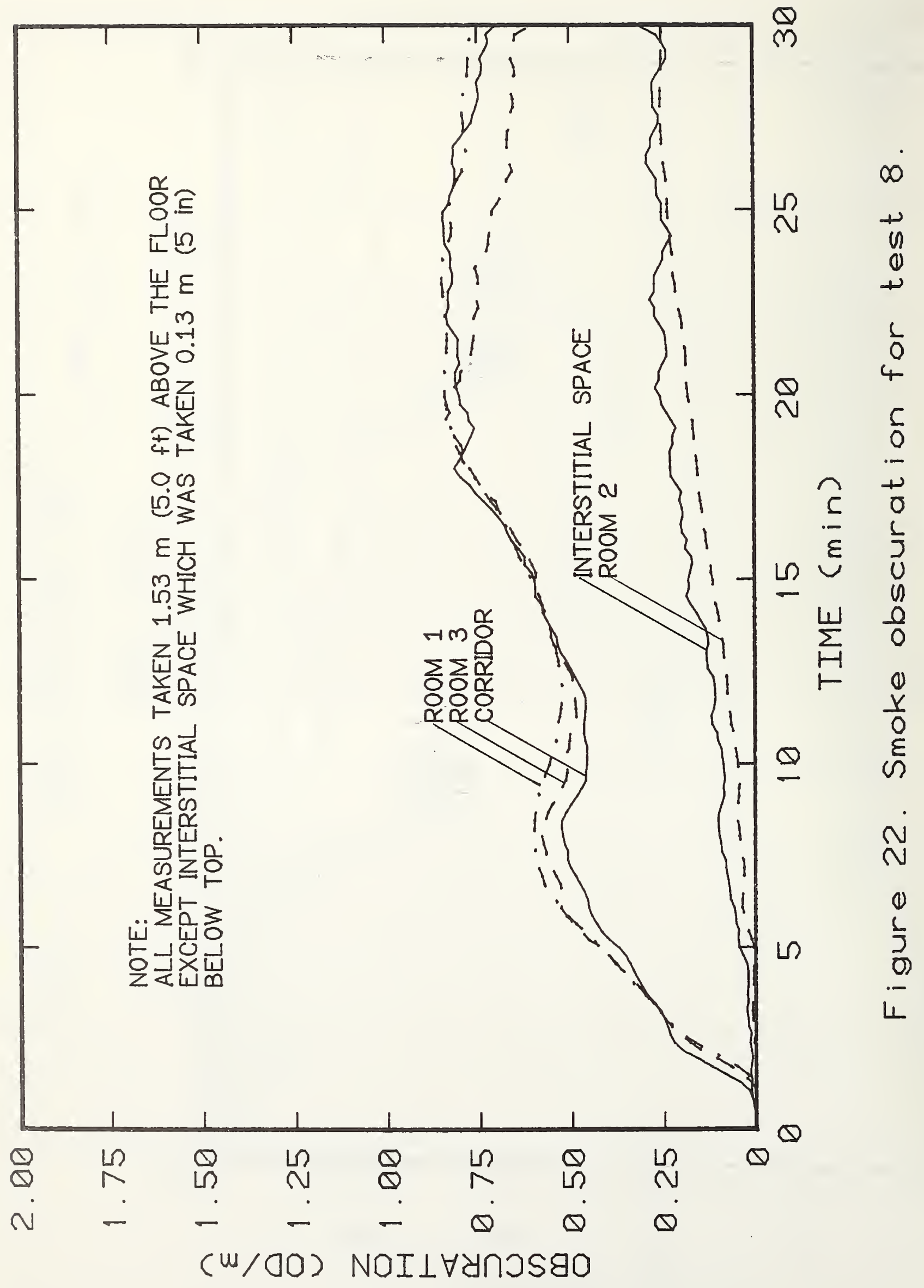




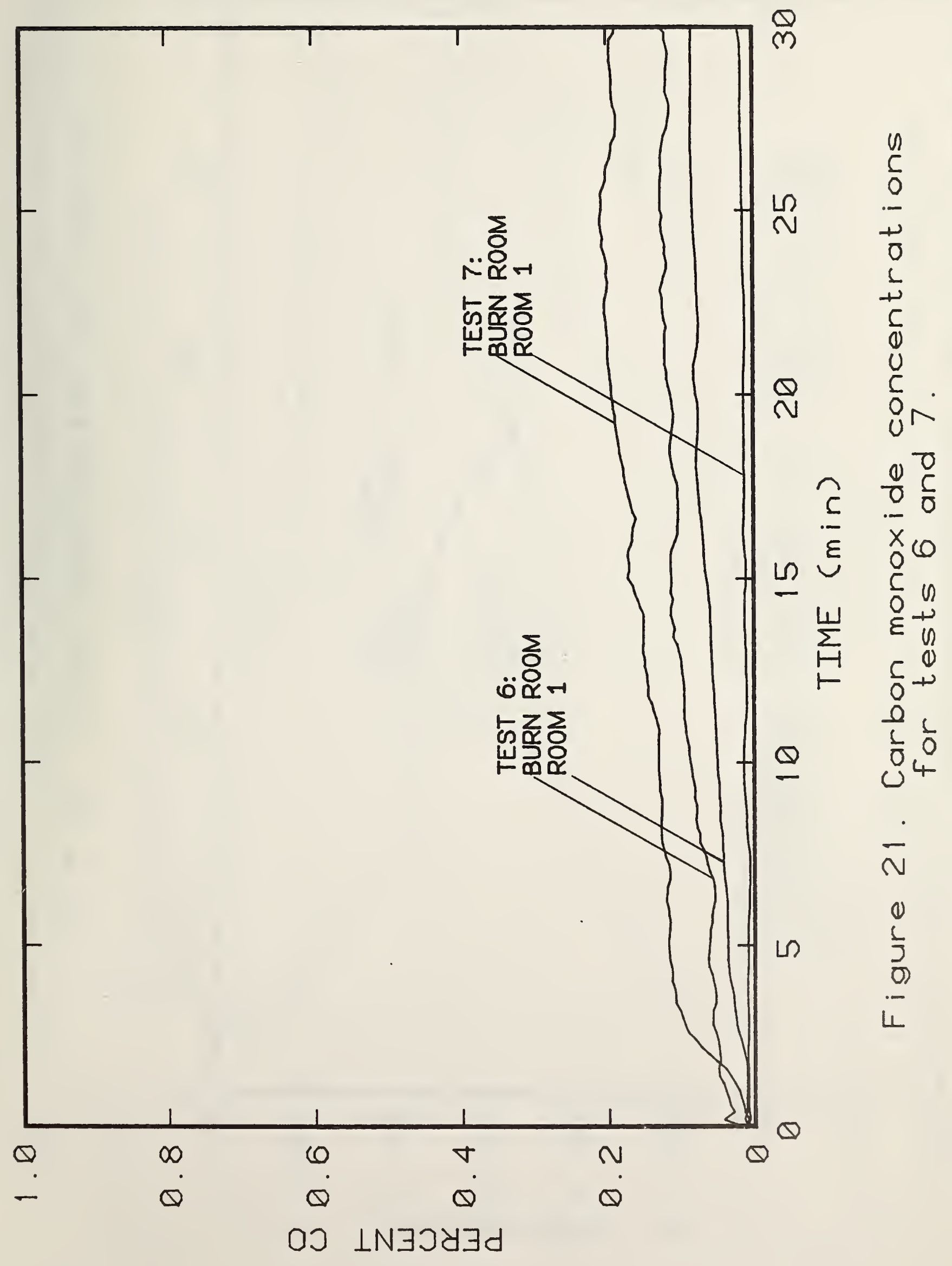




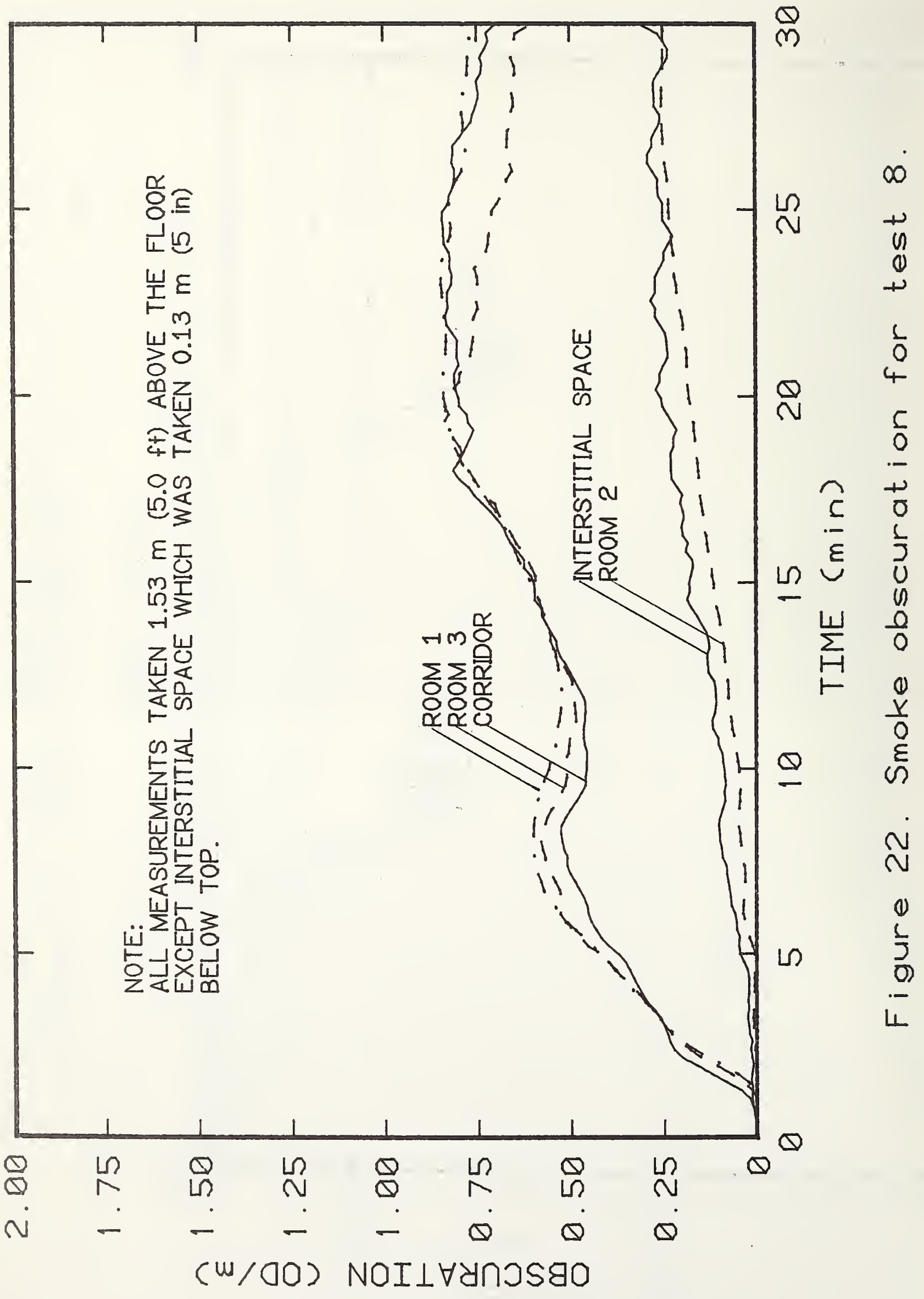




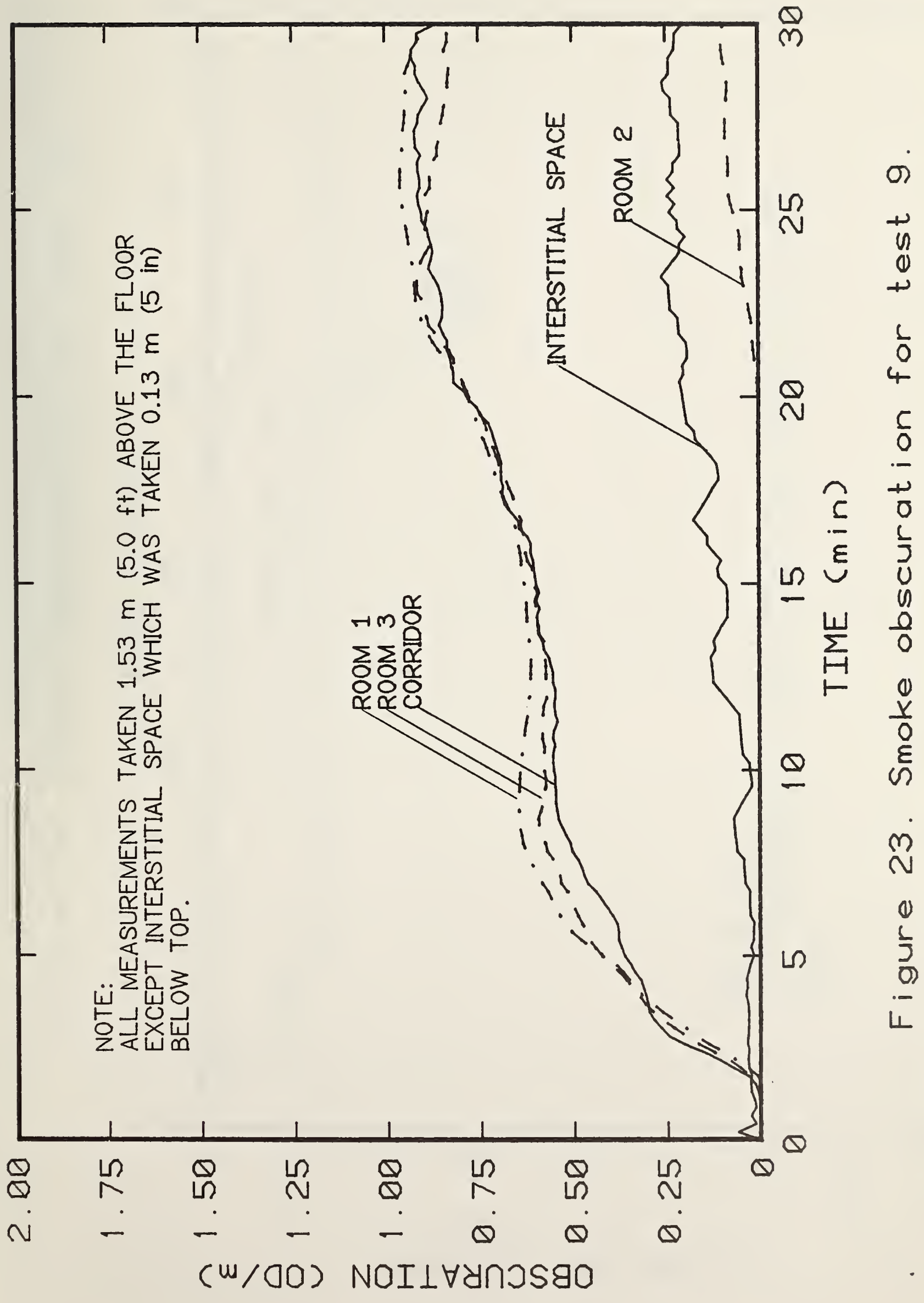




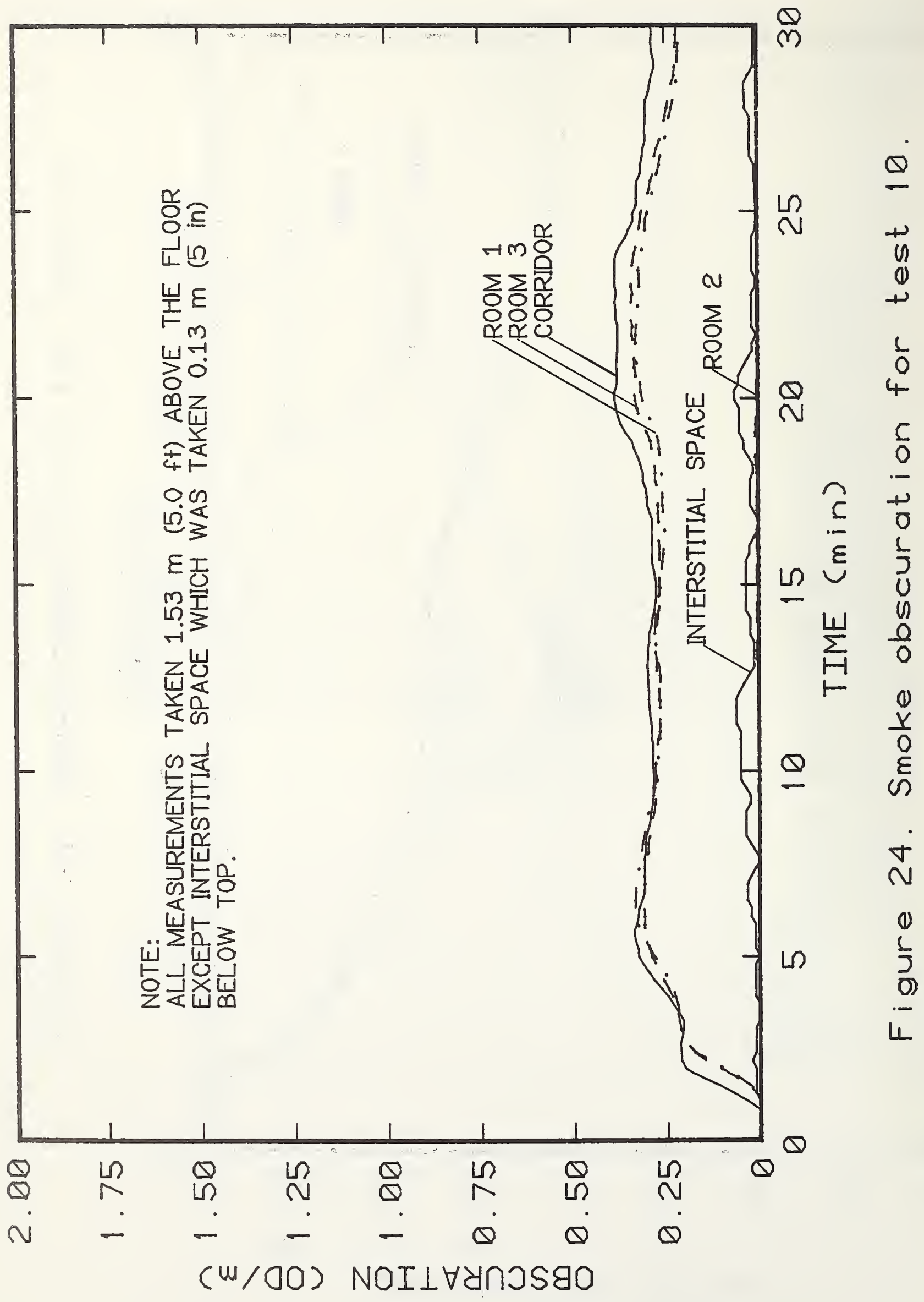




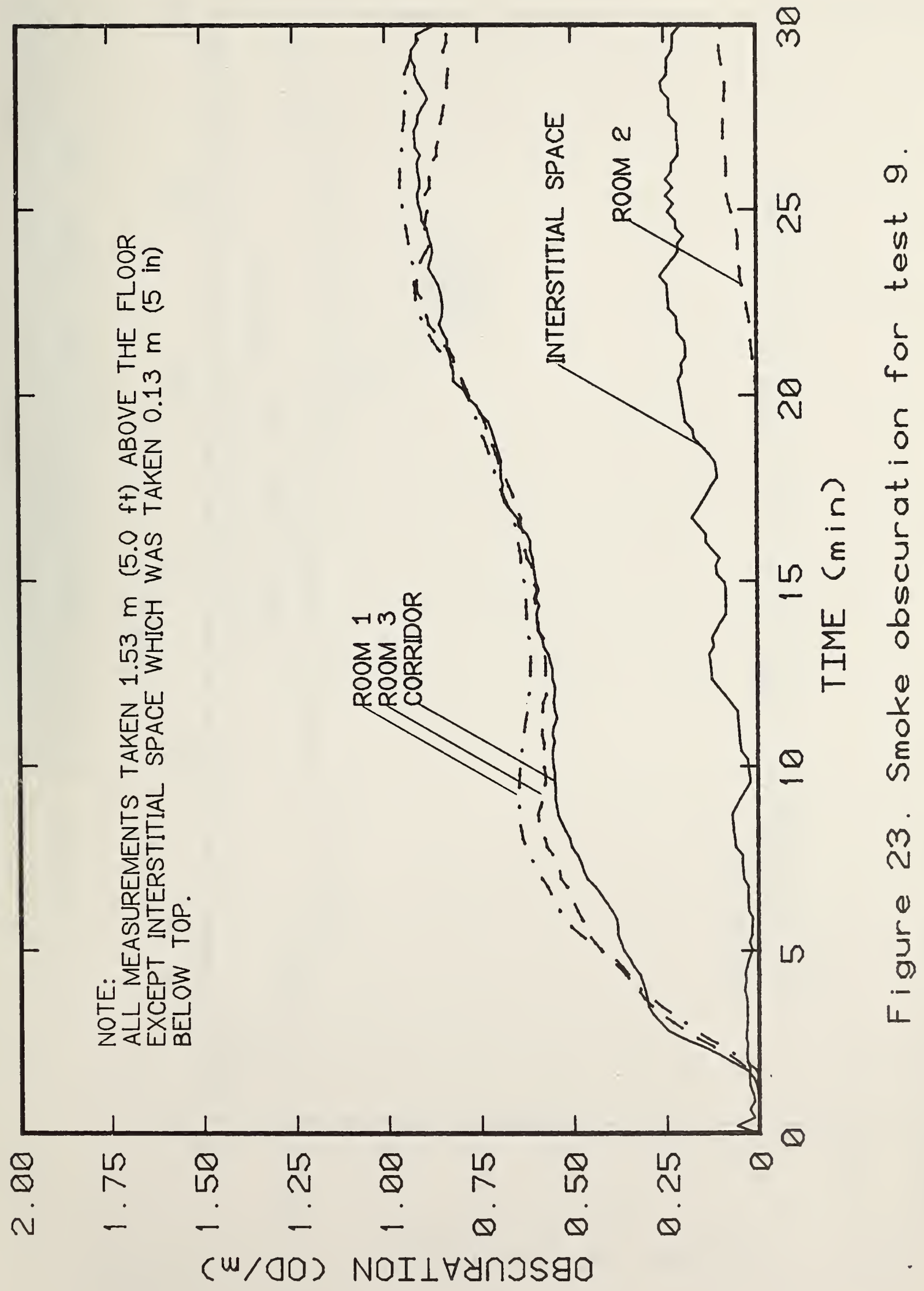




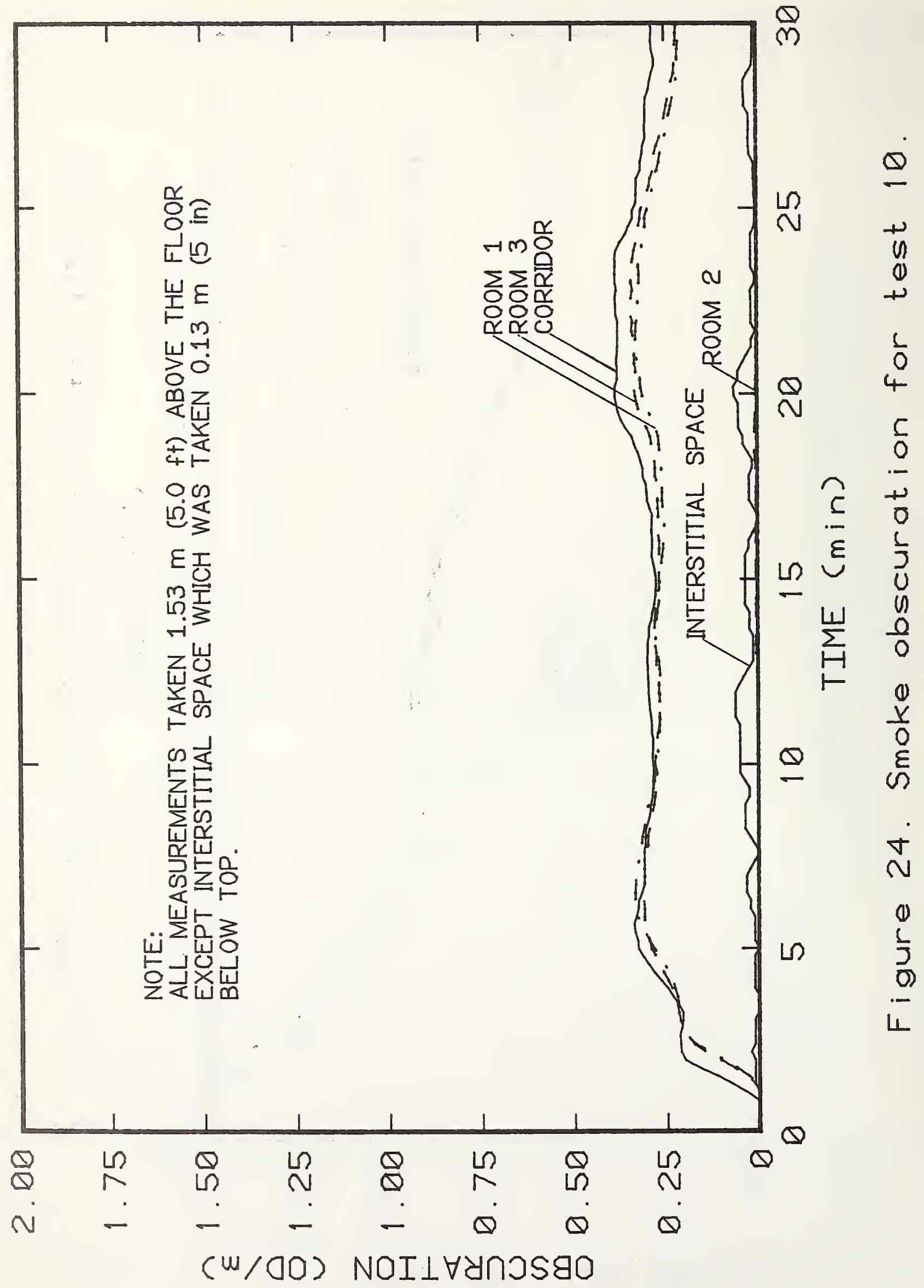




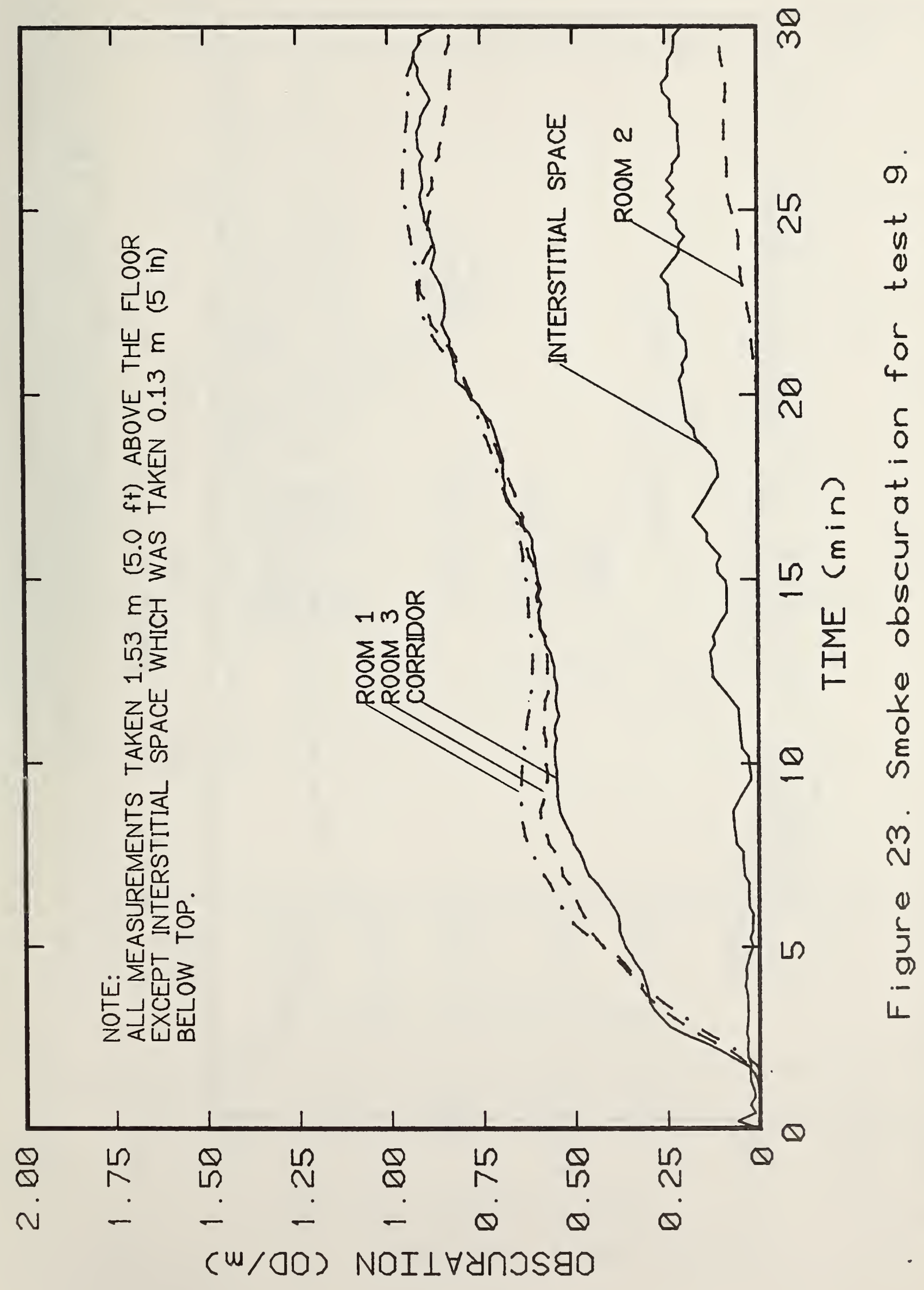




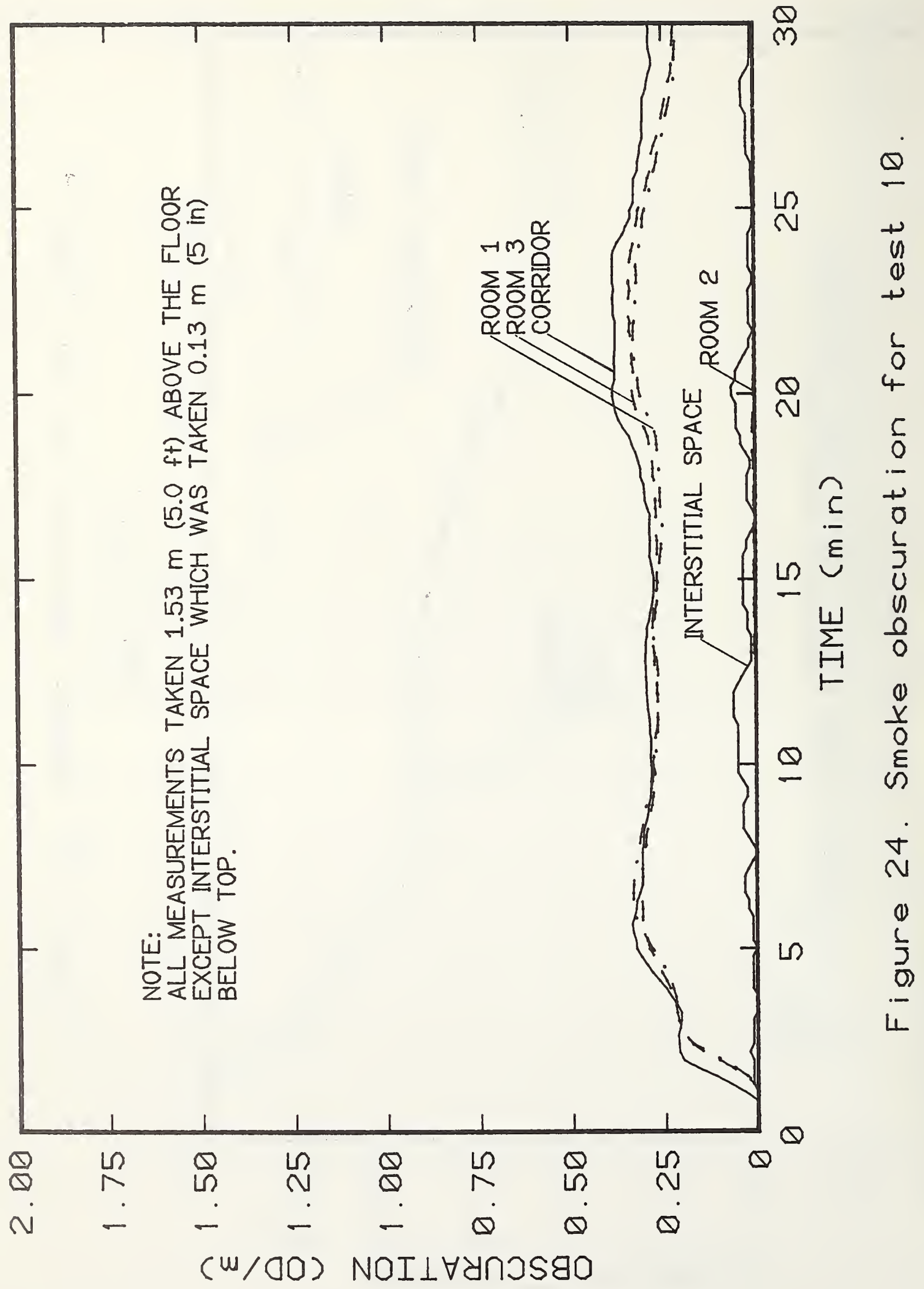



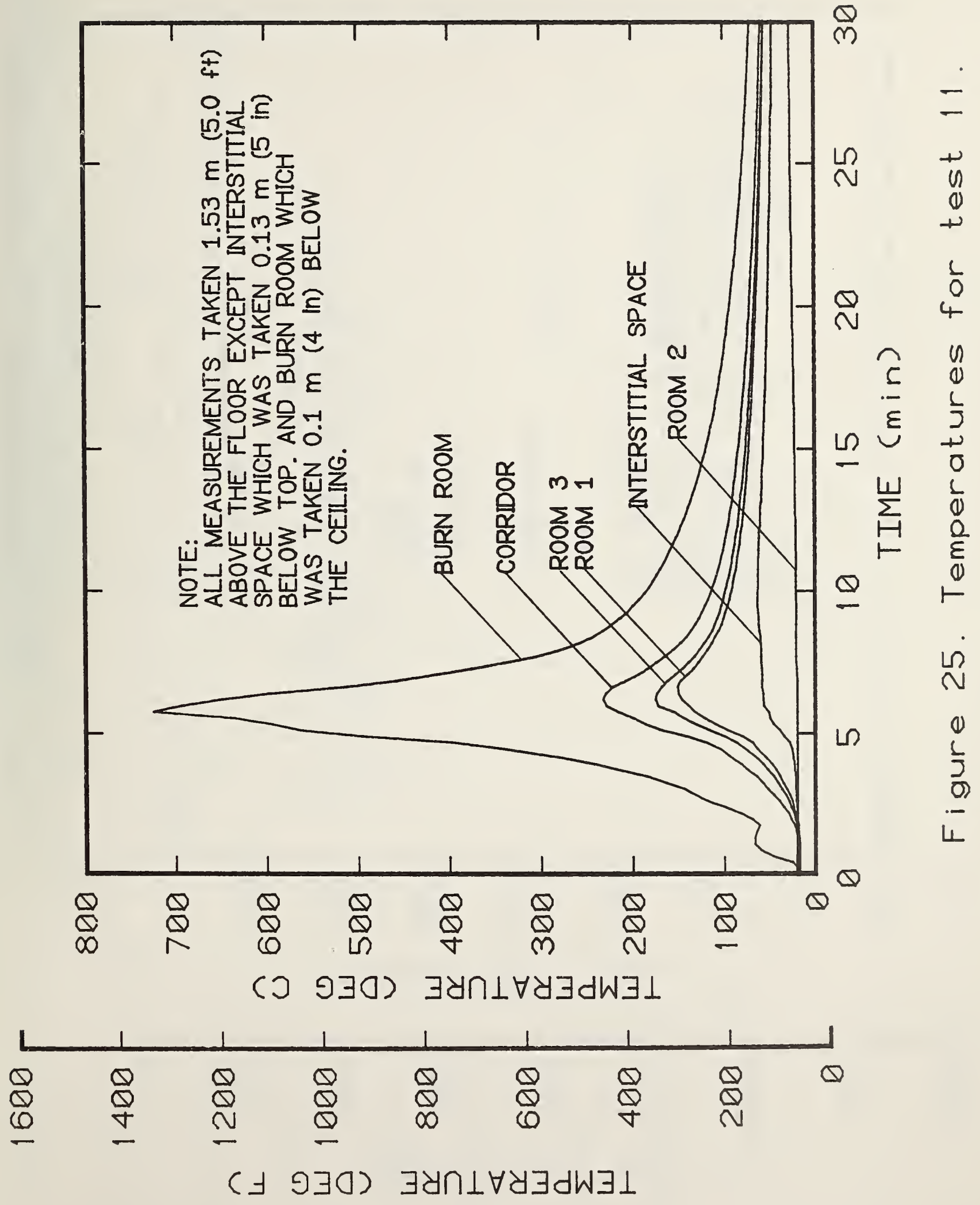

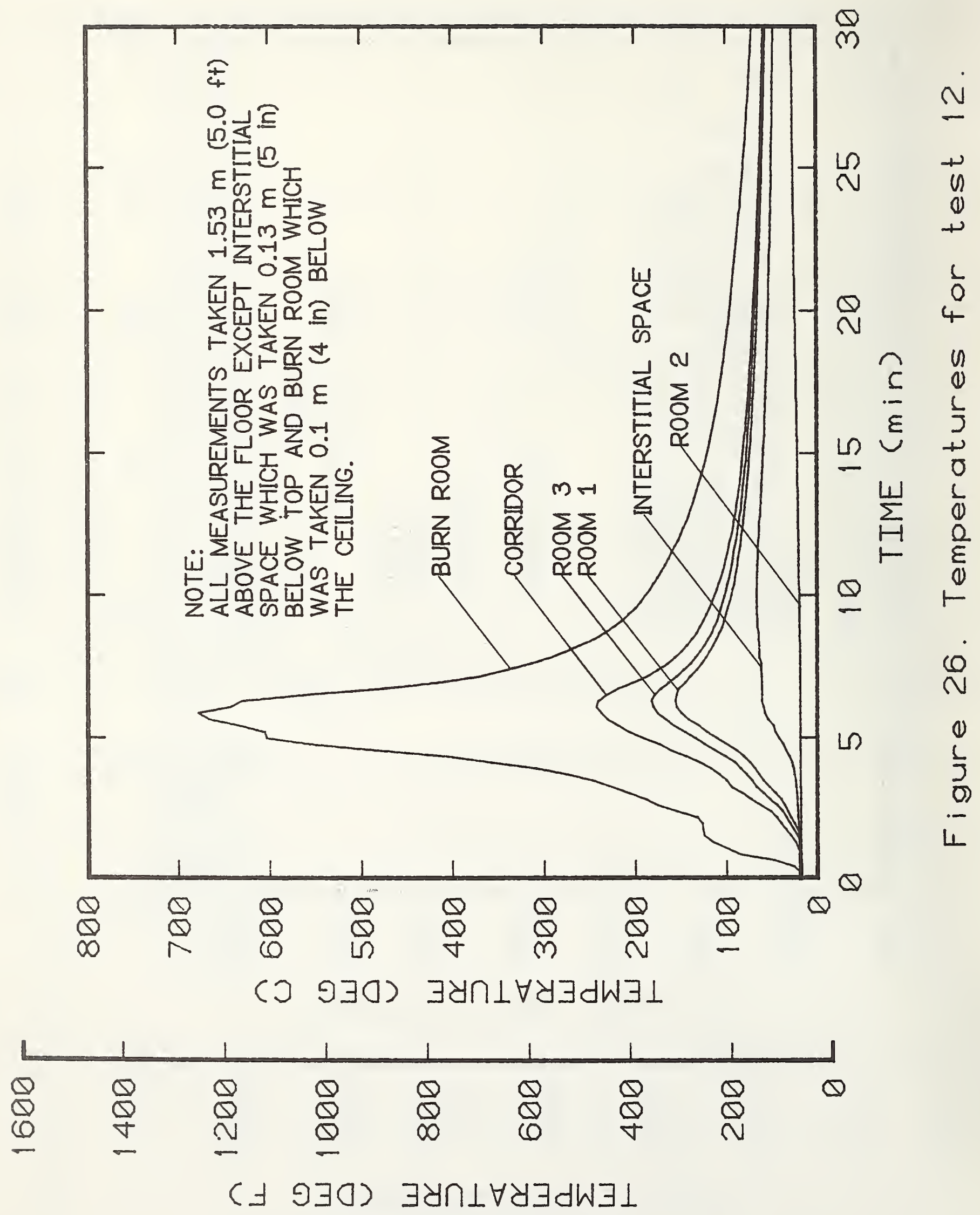


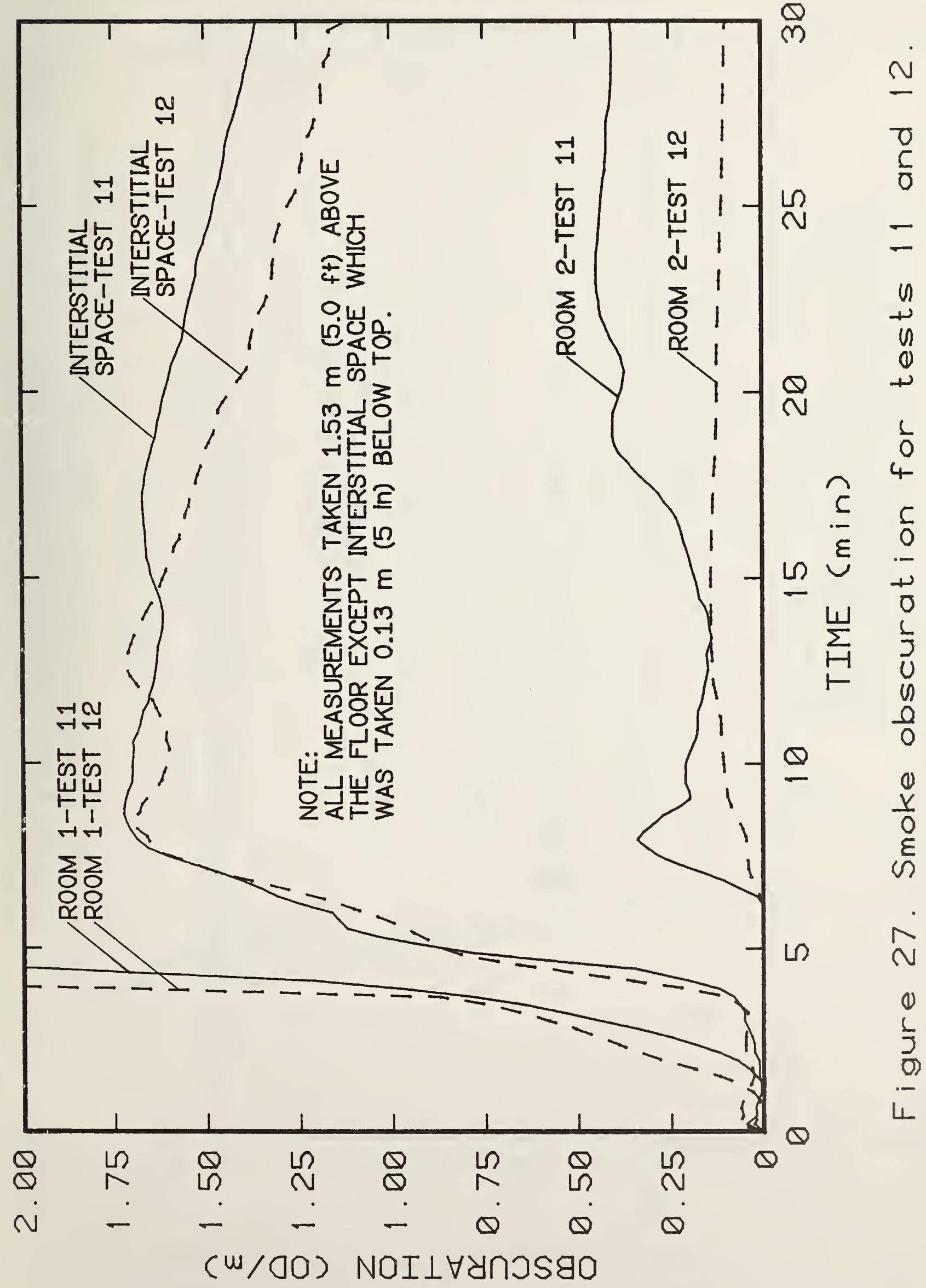




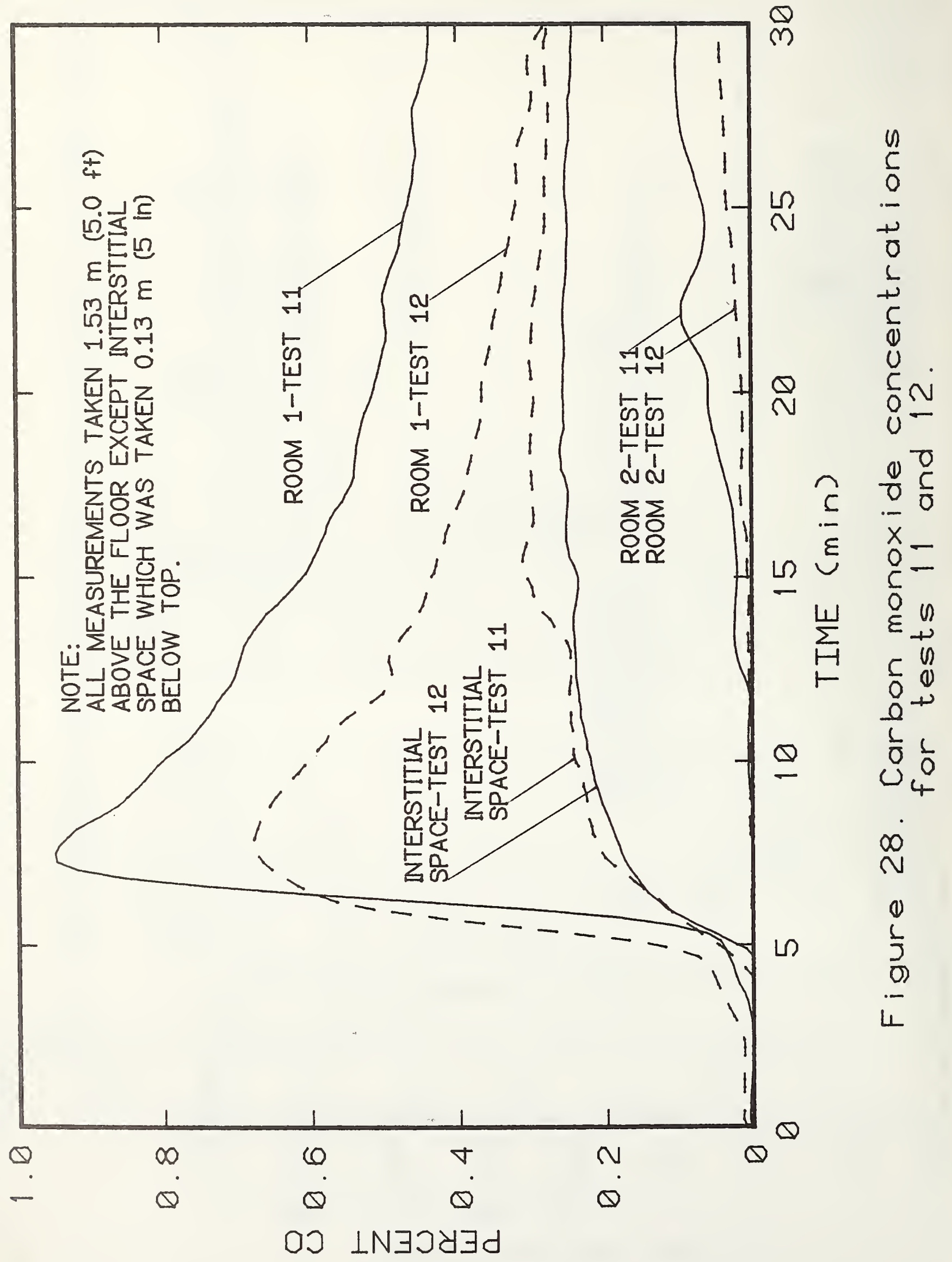




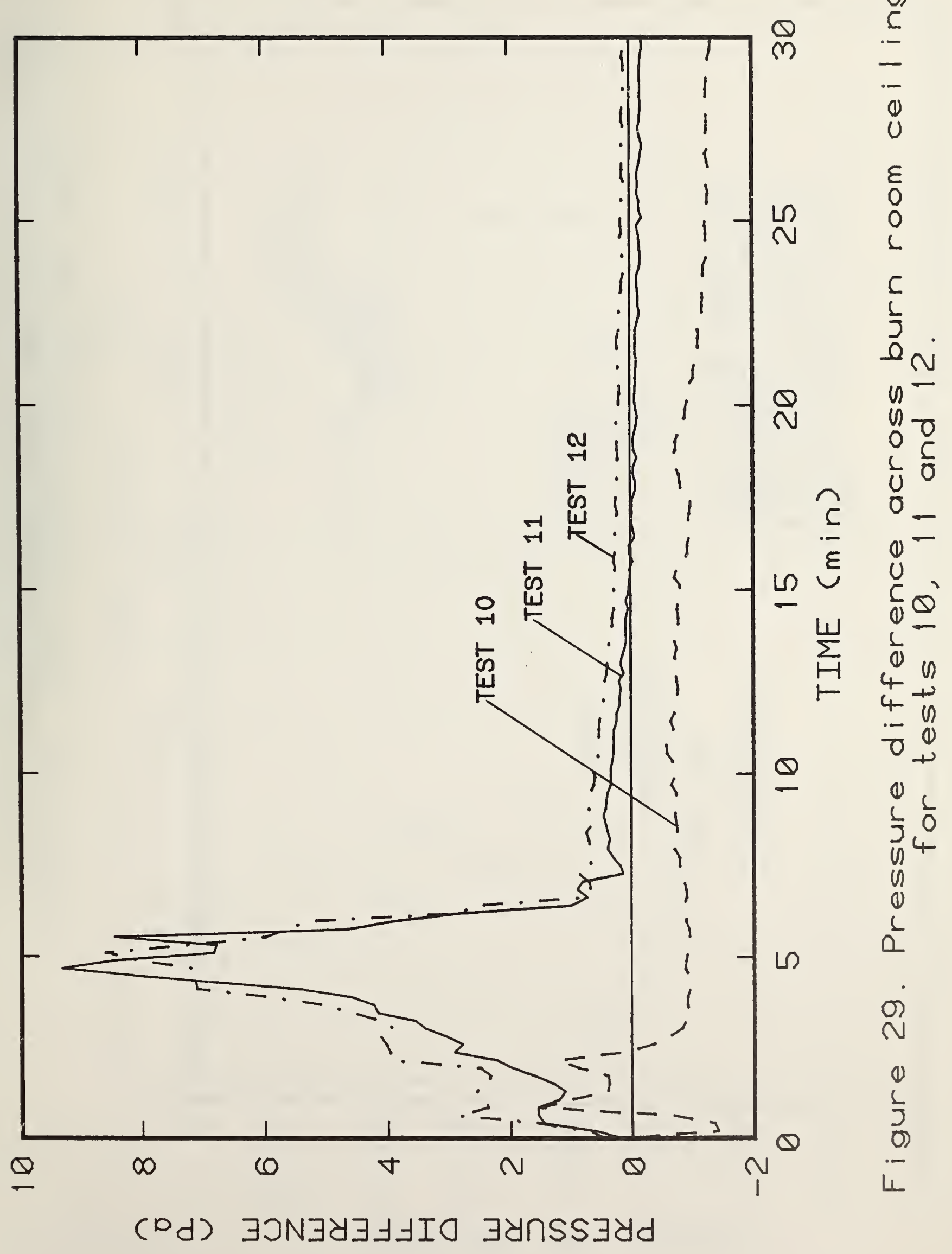




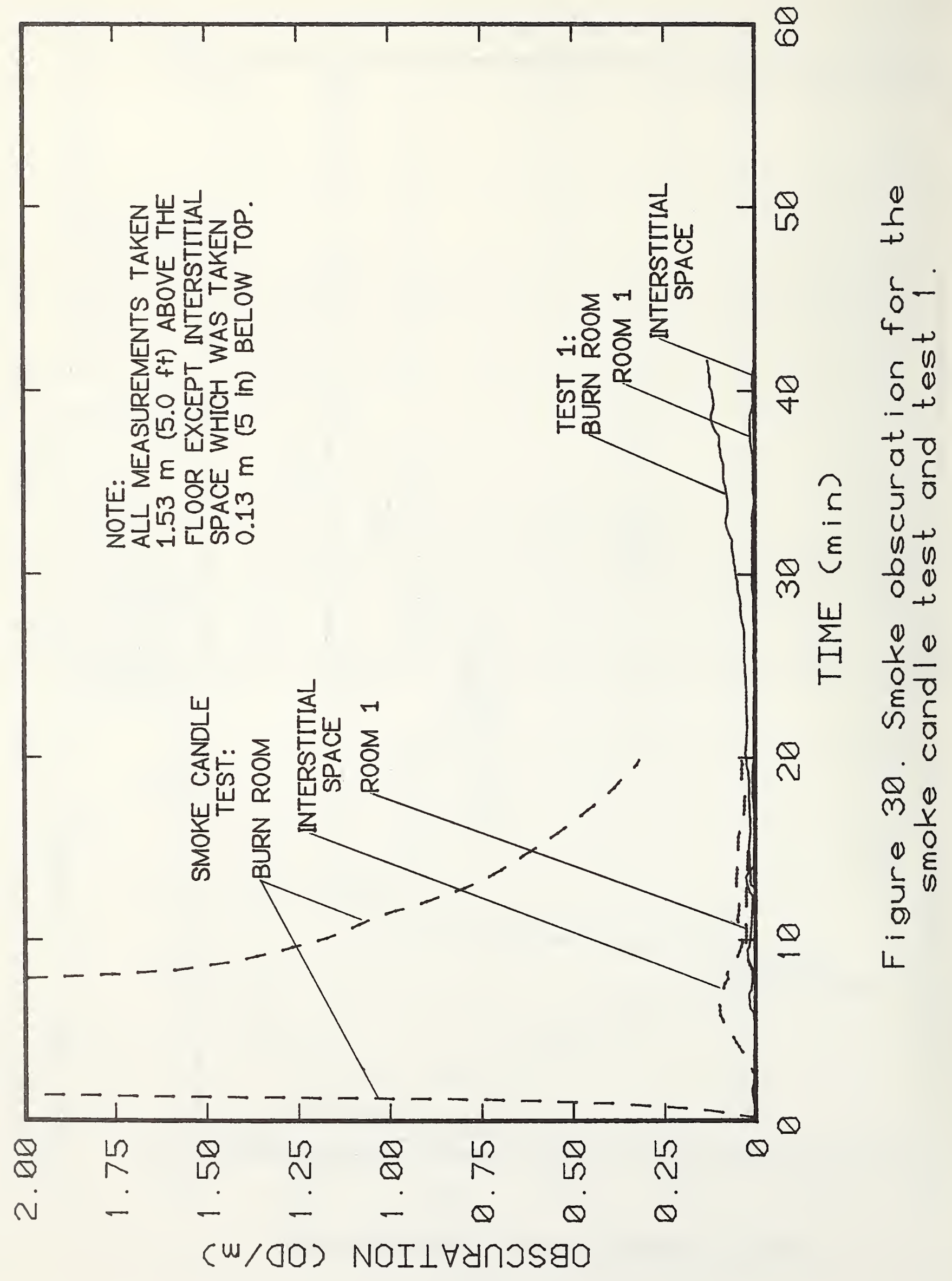


Table 1. Fan Schedule

\begin{tabular}{llll}
$\begin{array}{c}\text { Fan } \\
\text { Number }\end{array}$ & $\begin{array}{c}\text { Capacity } \\
(\text { cfm })\end{array}$ & \multicolumn{1}{c}{ Type } & Use \\
\hline 1 & 500 & Centrifugal & Supply \\
2 & 500 & Centrifugal & Exhaust \\
3 & 300 & Radial & Ventilation \\
4 & 120 & Radial & of inter- \\
5 & 120 & Radial & stitial space \\
6 & 300 & Radial & \\
\hline
\end{tabular}


Burn room $0.1 \mathrm{~m}$ ( 4 in) below ceiling Burn room $0.2 \mathrm{~m}$ ( 8 in) below ceiling Burn room $0.3 \mathrm{~m}$ (12 in) below ceiling Burn room $0.4 \mathrm{~m}$ (16 in) below ceiling Burn room $0.8 \mathrm{~m}$ ( $31 \mathrm{in}$ ) below ceiling Burn room $1.2 \mathrm{~m}(3.9 \mathrm{ft})$ below ceiling Burn room floor Burn room doorway $0.1 \mathrm{~m}$ ( $4 \mathrm{in}$ ) below top Burn room doorway $0.1 \mathrm{~m}$ ( $4 \mathrm{in}$ ) above floor Burn room floor under bed Burn room floor under wastebasket Burn room $0.13 \mathrm{~m}$ (5 in) below ceiling (1) Burn room $1.53 \mathrm{~m}(5.0 \mathrm{ft})$ above floof $(1)$ Burn room $0.81 \mathrm{~m}$ (32 in) above floor Room 1 - $1.53 \mathrm{~m}(5.0 \mathrm{ft})$ above floor Room 2 - $1.53 \mathrm{~m}(5.0 \mathrm{ft})$ above floor Room $3-1.53 \mathrm{~m}(5.0 \mathrm{ft})$ above floor Corridor $1.53 \mathrm{~m}(5.0 \mathrm{ft})$ above floor Corridor $0.13 \mathrm{~m}$ (5 in) below ceiling Interstitial space $0.76 \mathrm{~m}$ (30 in) below top Interstitial space $0.13 \mathrm{~m}$ ( 5 in) below top 1 ) Window of room $1-0.1 \mathrm{~m}$ (4 in) below top Window of room $2-0.1 \mathrm{~m}$ (4 in) above bottom (1) Outside air

Burn room doorway $0.1 \mathrm{~m}$ (4 in) below top (2) Burn room doorway $1.53 \mathrm{~m}(5.0 \mathrm{ft})$ above floor

30

31

32

33

34

35

36

37

38

39

$30 \mathrm{~A}$

$31 \mathrm{~A}$
Smoke Meters

Burn room $0.13 \mathrm{~m}$ (5 in) below ceiling(1)

Burn room $1.53 \mathrm{~m}$ ( $5.0 \mathrm{ft}$ ) above floor $(1)$

Burn room $0.81 \mathrm{~m}$ (32 in) above floor

Room $1-1.53 \mathrm{~m}(5.0 \mathrm{ft})$ above floor

Room $2-1.53 \mathrm{~m}(5.0 \mathrm{ft})$ above floor

Room 3 - $1.53 \mathrm{~m}(5.0 \mathrm{ft})$ above floor

Corridor $1.53 \mathrm{~m}$ (f.0 ft) above floor

Corridor $0.13 \mathrm{~m}$ (5 in) below ceiling

Insterstitial space $0.76 \mathrm{~m}$ (30 in) below top

Insterstitial space $0.13 \mathrm{~m}$ ( $5 \mathrm{in}$ ) below $59 p$

Burn room doorway $0.1 \mathrm{~m}$ ( 4 in) below top

Burn room doorway $1.53 \mathrm{~m}(5.0 \mathrm{ft})$ above floor

\footnotetext{
1 These instruments were only used for tests 1-3.

2 These instruments were used for tests $4-6$ and 8-10.
} 
Table 2. List of Instrumentation (cont'd)

Number

40

41

42

43

44

Number

50

51

54

55

Number

56
Co Probes

Burn room $1.53 \mathrm{~m}(5.0 \mathrm{ft})$ above floor ${ }^{(3)}$

Room $1-0.81 \mathrm{~m}$ (32 in) above floor

Room $2-0.81 \mathrm{~m}$ (32 in) above floor

Room 3 - $0.81 \mathrm{~m}$ (32 in) above floor

Interstitial space $0.76 \mathrm{~m}$ (30 in) below top

Velocity Probes

Burn room doorway $0.1 \mathrm{~m}$ ( 4 in) below top

Burn room doorway $0.1 \mathrm{~m}$ ( $4 \mathrm{in}$ ) above bottom,

Window of room $1-0.1 \mathrm{~m}$ (4 in) below top

Window of room $1-0.1 \mathrm{~m}$ (4 in) above bottom

Differential Pressure

Across burn room ceiling

\footnotetext{
$1_{\text {These instruments were only used for tests } 1-3 .}$

3 These instruments malfunctioned during test 8 .
} 


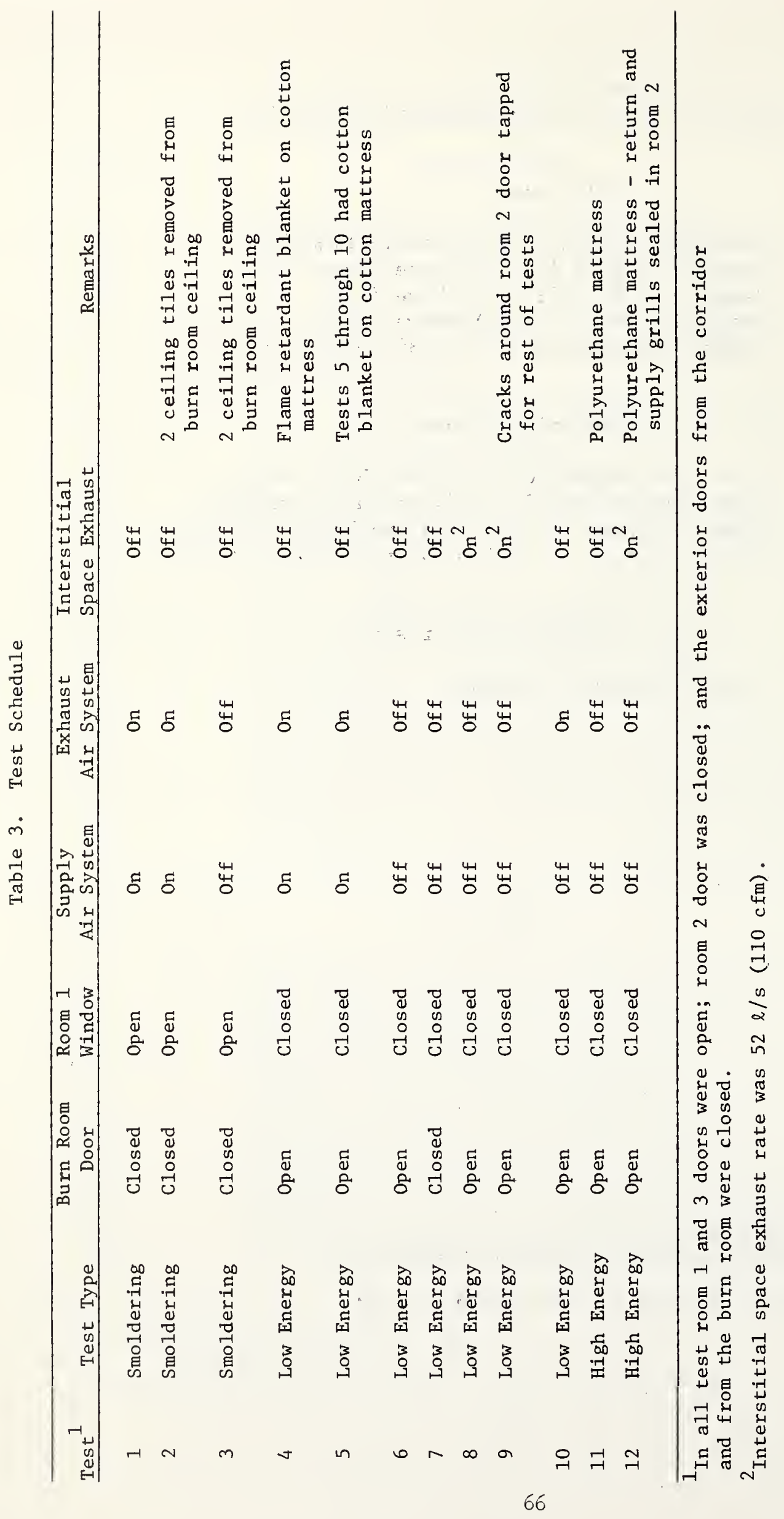


Table 4. Ignition Source

Wastebasket -- Polyethylene wastebasket

Size: $248 \mathrm{~mm} \times 178 \mathrm{~mm} \times 254 \mathrm{~mm}$ high Weight: $282 \mathrm{~g}(.6 \mathrm{lb})$

Trash contents, in order of stacking

$$
\begin{aligned}
& 1 \text {-- Polyethylene liner } \\
& 16 \text {-- Sheets of newspaper } \\
& 1 \text {-- Paper cup, } 85 \mathrm{~g} \text { ( } 3 \mathrm{oz.}) \text {, crumpled } \\
& 2 \text {-- Sheets of writing paper } \\
& 3 \text {-- Tissues, paper handkerchief, crumpled } \\
& 1 \text {-- Cigarette pack, crumpled } \\
& 1 \text {-- Milk carton, } 227 \mathrm{~g}(8 \mathrm{oz} .) \\
& 2 \text {-- Paper cup, } 85 \mathrm{~g}(3 \mathrm{oz.}), \text { crumpled } \\
& 1 \text {-- Cigarette pack, crumpled } \\
& 1 \text {-- Sheet of writing paper, crumpled } \\
& 2 \text {-- Tissues, paper handkerchief, crumpled }
\end{aligned}
$$

Total weight of contents: $443 \mathrm{~g}(.97 \mathrm{lb})$

Combined weight, wastebasket and contents: $725 \mathrm{~g}$ ( $1.6 \mathrm{lb})$ 
Table 5. Technical Data for Mattress and Bedding for Tests $4-10$

\begin{tabular}{lllll}
\hline \multicolumn{1}{c}{ Mattress } & Width & Size (m) & Length & $\begin{array}{r}\text { Total } \\
\text { Weight } \\
\text { (kg) }\end{array}$ \\
\hline $\begin{array}{l}\text { Fire Retardant } \\
\text { Cotton Innerspring }\end{array}$ & 0.91 & 2.03 & 0.17 & 23 \\
\hline
\end{tabular}

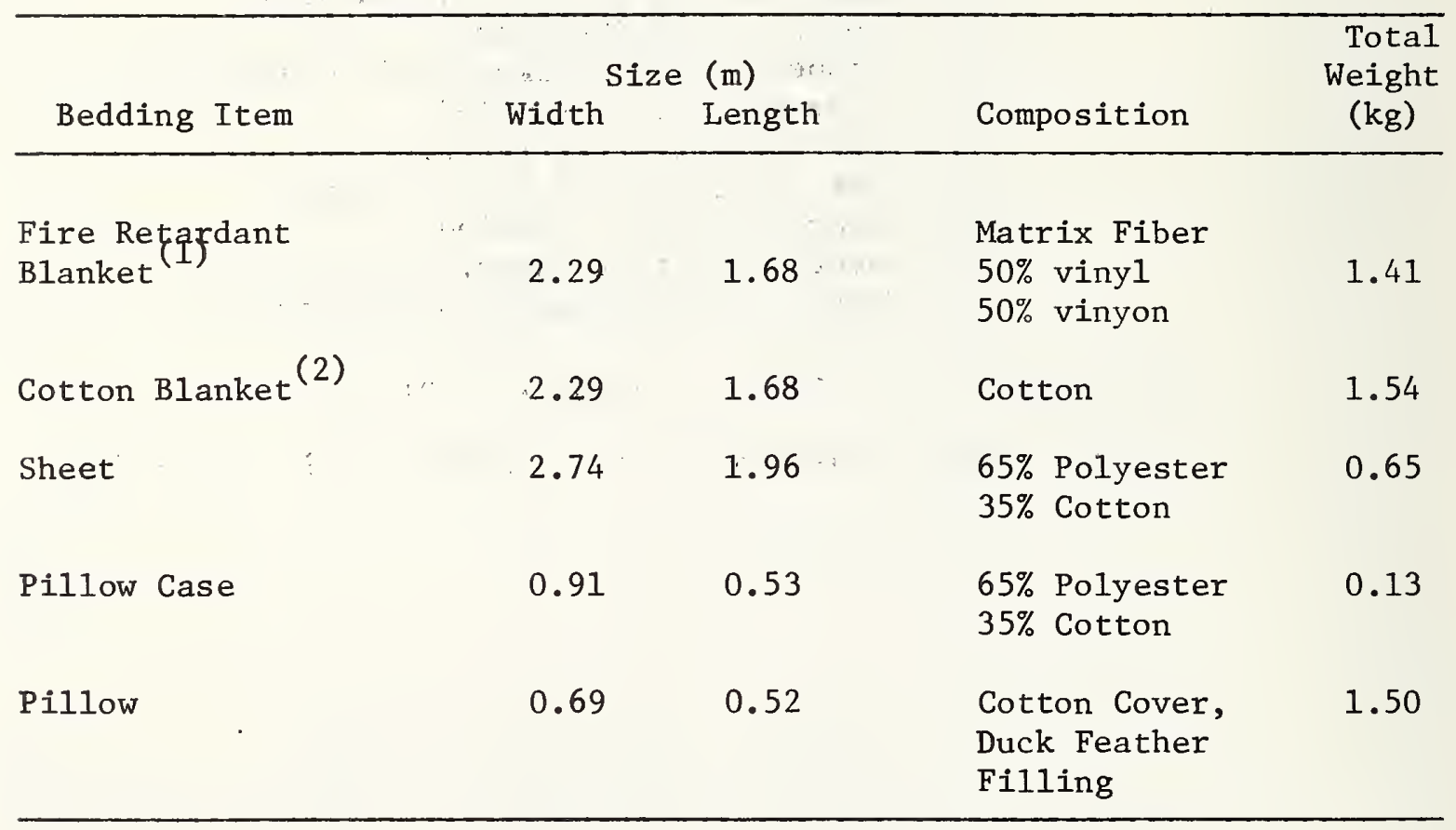

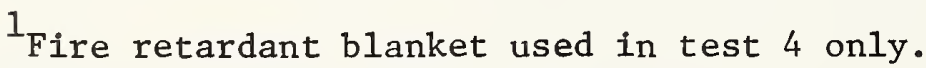
${ }^{2}$ Cotton blanket used in tests 5-10. 
Table 6. Technical Data for Mattress and Bedding for Tests 11 and 12

\begin{tabular}{lccccc}
\hline Mattress & Width & $\begin{array}{c}\text { Size (m) } \\
\text { Length }\end{array}$ & $\begin{array}{c}\text { Total } \\
\text { Thight } \\
(\mathrm{kg})\end{array}$ & $\begin{array}{c}\text { Weight } \\
\text { Combustibles } \\
(\mathrm{kg})\end{array}$ \\
\hline $\begin{array}{l}\text { Polyurethane } \\
\text { Innerspring }\end{array}$ & 0.89 & 2.03 & 0.17 & 15 & 6 \\
\hline
\end{tabular}

\begin{tabular}{|c|c|c|c|c|}
\hline Bedding Item & $\begin{array}{l}\text { Siz } \\
\text { Width }\end{array}$ & $\begin{array}{l}\text { (m) } \\
\text { Length }\end{array}$ & Composition & $\begin{array}{c}\text { Total } \\
\text { Weight } \\
\text { (kg) }\end{array}$ \\
\hline Spread & 2.79 & 1.93 & $\begin{array}{l}50 \% \text { Cotton } \\
50 \% \text { Polyester }\end{array}$ & 1.07 \\
\hline $\begin{array}{l}\text { Sheet and } \\
\text { Drawsheet }\end{array}$ & 2.64 & 1.83 & $\begin{array}{l}50 \% \text { Cotton } \\
50 \% \text { Polyester }\end{array}$ & 0.60 \\
\hline Pillow Case & 0.91 & 0.53 & $\begin{array}{l}50 \% \text { Cotton } \\
50 \% \text { Polyester }\end{array}$ & 0.60 \\
\hline $\begin{array}{l}\text { Pillow } \\
\text { - Filling } \\
\text { - Cover }\end{array}$ & 0.69 & 0.52 & $\begin{array}{l}\text { Polyurethane } \\
\text { Cotton }\end{array}$ & $\begin{array}{l}0.67 \\
0.16\end{array}$ \\
\hline $\begin{array}{l}\text { Pillow } \\
\text { Protector }\end{array}$ & 0.69 & 0.53 & Polyviny1 chloride & 0.90 \\
\hline
\end{tabular}


Table 7. Times to Hazard Level Due

to CO Concentrations

\begin{tabular}{|c|c|c|c|c|}
\hline \multirow[b]{3}{*}{ Test } & \multirow{3}{*}{\multicolumn{2}{|c|}{ Space }} & \multicolumn{2}{|c|}{ Time (min) } \\
\hline & & & $\mathrm{COHb}$ & $\mathrm{CO}$ \\
\hline & & & $>25 \%$ & $>1 \%$ \\
\hline 7 & Burn & Room & 22.6 & - \\
\hline 11 & Burn & Room & - & 4.7 \\
\hline 11 & Room & 1 & 9.2 & - \\
\hline 11 & Room & 3 & 9.5 & - \\
\hline 11 & Inter & rstitial Space & 19 & - \\
\hline 12 & Burn & Room ${ }^{(1)}$ & - & - \\
\hline 12 & Room & 1 & 9.8 & - \\
\hline 12 & Room & 3 & 11.1 & - \\
\hline 12 & Inter & rstitial Space & 18 & - \\
\hline
\end{tabular}

${ }^{1}$ Co analyzer failure. 
Table 8. Smoke Detector Activation Times

\begin{tabular}{|c|c|c|c|}
\hline \multirow[b]{2}{*}{ Test } & \multirow[b]{2}{*}{ Test Type } & \multicolumn{2}{|c|}{ Time $(\mathrm{sec})$} \\
\hline & & Burn Room & Corridor \\
\hline 1 & Smoldering & 3567 & $\mathrm{~N} / \mathrm{A}$ \\
\hline 2 & Smoldering & 2679 & N/A \\
\hline 3 & Smoldering & 1604 & N/A \\
\hline 4 & Low Energy & 43.7 & 71.2 \\
\hline 5 & Low Energy & 37.2 & 49.4 \\
\hline 6 & Low Energy & 15.2 & 26.7 \\
\hline 7 & Low Energy & 20.0 & 2024 \\
\hline 8 & Low Energy & 34.9 & 53.1 \\
\hline 9 & Low Energy & 54.5 & 72.3 \\
\hline 10 & Low Energy & 54.4 & 66.6 \\
\hline 11 & High Energy & 20.4 & 37.4 \\
\hline 12 & High Energy & 22.0 & 42.6 \\
\hline
\end{tabular}

Note: $\mathrm{N} / \mathrm{A}=$ not activated during test 
NBS-114A (REV. 2-80)

U.S. DEPT. OF COMM.

BIBLIOGRAPHIC DATA

SHEET (See instruction s)

1. PUBLICATION OR

REPORT NO.

NBSIR $81-2444$

February 1982

4. TITLE AND SUBTITLE

SMOKE MOVEMENT THROUGH A SUSPENDED CEILING SYSTEM

5. $\operatorname{AUTHOR}(S)$

John H. Klote

6. PERFORMING ORGANIZATION (If joint or other than NBS, see instructions)

NATIONAL BUREAU OF STANDARDS

DEPARTMENT OF COMMERCE

WASHINGTON, D.C. 20234

7. Contract/Grant No.

9. SPONSORING ORGANIZATHOH IAAME AND COMPLETE ADDRESS (StFEC, City, S1OtE, ZIP)

Veterans Administration

Department of Health and Human Services

Office of Construction Research and Washington, D.C. 20201

Washington, D.C. 20420

10. SUPPLEMENTARY NOTES

Document describes a computer program; SF-185, FIPS Software Summary, is attached.

11. ABSTRACT (A 200-word or less factual summary of most significant information. If document includes a significant bibliography or literature survey. mention it here)

A series of full-scale tests were conducted to evaluate smoke movement through a suspended ceiling and into an interstitial space of a hospital type facility. A test facility specifically constructed for this project is described. The test series consisted of one smoke candle test and 12 fire tests including both smoldering and flaming fires. Smoke movement through the suspended ceiling system was evaluated in terms of the total smoke movement through the test facility. The effects of ventilation and smoke exhaust on smoke concentration in the test facility were investigated.

12. KEY WORDS (Six to twelve entries; alphabetical order; capitalize only proper names; and separate key words by semicolons) Ceiling systems; hazard analysis; hospitals; interstitial space; mattresses; smoke control; smoke exhaust; smoke movement; ventilation systems

13. AVAILABILITY

Xat Unlimited

For Official Distribution. Do Not Release to NTIS

Order From Superintendent of Documents, U.S. Government Printing Office, Washington, D.C. 20402.

X Order From National Technical Information Service (NTIS), Springfield, VA. 2216I

14. NO. OF

PRINTED PAGES

77

15. Price

$\$ 10.50$ 

